\title{
Processing of polymer wood composite material from pine cone and the binder of phenol formaldehyde/PVAc/molasses and improvement of its properties
}

Melih Şahinöz ( $\nabla$ melih.sahinoz@gazi.edu.tr)

Gazi University: Gazi Universitesi https://orcid.org/0000-0002-4159-1535

Hüseyin Yılmaz ARUNTAŞ

Gazi University: Gazi Universitesi

Metin GÜRÜ

Gazi University Faculty of Engineering: Gazi Universitesi Muhendislik Fakultesi

\section{Research Article}

Keywords: Polymer composite material, Pine cone, Molasses, Waste colemanite, Nonflammability, Flexural strength

Posted Date: January 11th, 2022

DOI: https://doi.org/10.21203/rs.3.rs-1211662/v1

License: (c) (1) This work is licensed under a Creative Commons Attribution 4.0 International License.

Read Full License

Version of Record: A version of this preprint was published at Case Studies in Construction Materials on March 1st, 2022. See the published version at https://doi.org/10.1016/j.cscm.2022.e01013. 


\section{Abstract}

This paper deals with the processing of polymer wood composite material from pine cone and the binder of phenol formaldehyde/PVAc/molasses and improvement of its properties. The production of pine cone based polymer binding and molasses added composite material, and the development of the nonflammability, insect attack and water resistance properties of this material has been studied in the research. To this end, pine cone, polyvinyl acetate (PVAc), phenol-formaldehyde, molasses, hemp fiber and waste colemanite have been used in the production of composite materials. It is aimed to produce a cheaper composite material less harmful to human health using plant based waste materials. According to the results of the flexural strength test conducted in the laboratory, the most suitable composite material producing parameters were detected as $0.25 \mathrm{filler} / \mathrm{binder}(\mathrm{f} / \mathrm{b})$ ratio, $35 \%$ molasses ratio, $100^{\circ} \mathrm{C}$ molding pressure temperature, $49 \mathrm{~kg} / \mathrm{cm}^{2}$ molding pressure, $240 \mu \mathrm{m}$ mean particle size, 20 minutes for molding pressure time, $20 \% \mathrm{PF}$ ratio and $0.5 \%$ hemp fiber ratio. It was determined that molasses could be used at a ratio of $35 \%$ for producing composite materials and, PF resin and hemp fiber samples provide the necessary water resistance. It was observed that the colemanite waste used in the mixture adds the nonflammability property to the composite material and decreases flexural strength and screw withdrawal strength.

\section{Introduction}

The term wood-based composite material is used for defining wood materials joined together with an adhesive [1]. Wood based composite materials are produced by binding small wood parts and lignocellulose materials by synthetic and other binder materials and holding them together under heat and pressure [2]. Wood based composite materials are commonly used for furniture production, building construction and packing [3]. However, the increase in demand for wood-based products and the scarcity of wood raw material sources highlighted the use of alternative raw materials for composite producing material $[3,4]$. Agricultural waste, herbal fibers and lignocellulose materials different from wood are among alternative raw material sources for producing wood-based composite materials [5]. Especially agricultural waste is the most appropriate alternative material for wood as they are cheap, abundant, renewable, easily processable and environment friendly $[6,7]$.

In literature, walnut shell [7], poppy [8], coffee husk [9], coconut fiber [10], wheat straw [11], tea leaves [12], tobacco stalk [13], cotton stalk [14] and corn cob [15] can be shown as examples among the agricultural waste material used for producing composite materials. One of the agricultural plants used in producing composite materials is industrial hemp [16]. Industrial hemp (Cannabis sativa) is a plant with fiber, seed, oil grown for bio-fuel or pharmaceuticals $[17,18]$. The biggest hemp fiber manufacturer countries, according to 2018 data, are ranked as China, South Korea and the Netherlands. The mean world hemp fiber production of 2018 was 60.000 tonnes [19].

Polymer resins such as phenol-formaldehyde (PF), urea-formaldehyde (UF), isocyanate and polyvinyl acetate (PVAc) are widely used as a binder materials for producing wood-based composite materials [20]. 
On the other hand, formaldehyde is a very toxic and carcinogenic material. The use of formaldehyde has been restricted in the production of industrial products as it is hazardous to human health [21]. Woodbased materials have three major disadvantages. Those are respectively flammability, water absorption and insect attack. Those disadvantages limit the field of use of wood-based materials [22]. Scientific researches are conducted to eliminate those disadvantages of wood based composites. For example, binders including lime, cement, plaster, silicate and magnesium as coating and filler materials are used for producing fire-resistant composite materials [23]. Mineral binders prevent the material from burning by coating lignocellulosic particles within the composite material and penetrating [24]. Colemanite has a monoclinic crystal structure and is among the most widely used boron minerals for generally producing boron oxide [25]. Turkey has $72 \%$ of the world's boron ore, and colemanite, tincal and ulexite are the boron minerals that are mined in Turkey [26]. A large amount of waste is formed during the production of boron minerals. These wastes cause both environmental pollution and an economic loss [27].

Molasses is fluid and sticky waste material arising at sugar beet or sugar cane processing during sugar production. Generally, $\sim 4 \%$ of the sugar beet produced in sugar factories arises as molasses [28]. The amount of sugar within molasses changes depending on the processing conditions and the sugar ratio of sugar raw material [29]. There are numerous studies including various processing conditions in composite material produce and various plant waste materials in the literature.

Viswanathan and Gothandapani [30] investigated for the optimum conditions to produce coconut fiberbased composite boards in their study. In the study, the most suitable resin ratio, curing temperature and curing time parameters were detected for producing the samples in the highest flexural strength. PF and UF were used as resin binder materials in sample production. In conclusion, the most suitable resin ratio, curing temperature and curing time were respectively determined as $16.7 \%, 138^{\circ} \mathrm{C}$ and 26 minutes in PF resin-based samples according to flexural strength. On the other hand, the most suitable resin ratio, curing temperature and curing time were respectively determined as $20.4 \%, 139^{\circ} \mathrm{C}$ and 17 minutes in UF resin-based samples. In the study conducted by Kim and Kim [31], using PVAc instead of melamineformaldehyde (MF) resin for coating and plywood material production for decreasing formaldehyde release was researched. Composite samples were prepared to add PVAc at the rates of $0 \%, 30 \%, 50 \%$, $70 \%$ and $100 \%$ by weight instead of MF. Additionally, the samples were prepared at $60 \sim 160^{\circ} \mathrm{C}$ press temperature, $110 \sim 240$ seconds press time and $3 \sim 12 \mathrm{kgf} / \mathrm{cm}^{2}$ pressure. As a result, it was determined that as press time, temperature and pressure increase for the samples, including more than $50 \%$ PVAc, mechanical resistance decreases, and formaldehyde release decreases, and samples are in E1 class for the samples prepared with PVAc ratio up to $30 \%$. Gürü et al. [22] examined a walnut Shell based polymer matrix composite board in their study. In the study, the effect of UF ratio, press temperature and press time on the mechanical properties of the composite board was detected. The highest flexural strength was obtained from the samples with filler/binder $(\mathrm{f} / \mathrm{b})$ resin ratio of 3 , press temperature of $70^{\circ} \mathrm{C}$ and press time of 25 minutes among the composite board samples produced. Furthermore, in the study fly ash at a ratio up to the ratio of $15 \%$ by weight was added to composite board mixtures instead of walnut shell, and thus the flame temperature of the composite board samples was decreased. On the other side 
PF, up to $35 \%$ was added to the composite board mixtures instead of UF, and water absorption and thickness swelling values of the mixtures were decreased. As a result, it was expressed that the composite samples obtained were affordable and fire resistant. In the study conducted by Xian-Qing et al. [32], the production steps which are necessary for producing coated decorative straw particleboard were examined. PVAc was mixed with a binder without formaldehyde, and a certain amount of flour was used as a binder for producing straw particleboard samples. The board samples were produced under the production conditions of $0.6,0.7$ and $0.8 \mathrm{MPa}$ pressure, 90,100 and $110^{\circ} \mathrm{C}$ press temperature and 120 , 180 and 240 seconds of hot pressing time. According to the test results, the highest bonding strength was obtained under the production conditions at $0.7 \mathrm{MPa}$ pressure, $90^{\circ} \mathrm{C}$ press temperature and 180 seconds hot pressing time. Gürü et al. [33] searched high temperature and fire resistant rice husk-based composite board production in the study that they conducted. In the study, composite samples were prepared at $65 / 50,75 / 50,80 / 50,85 / 50$ and $95 / 50 \mathrm{f} / \mathrm{b}$ rates and UF was used as a binder. According to the test results, the highest flexural strength was determined as $\sim 11 \mathrm{MPa}$ in the samples prepared at a $75 / 50 \mathrm{f} / \mathrm{b}$ ratio. On the other side, it was determined that the limit oxygen index (LOI) of the samples increased up to $40 \%$ as the filler rate within the samples increased. Adding PF up to $25 \%$ by weight into UF in composite board sample production significantly decreased the water absorption capacity of the samples. Furthermore, it is expressed that it is important to bring agricultural waste to the economy by using them in producing composite materials. Tigabe et al. [34] examined the physical and mechanical properties of composite material produced using sawdust, rice husk, jute fibers and PVAc resin to produce bio-based particleboard. Composite samples were produced with jute fibers at a ratio between 5 30\%. The highest physical and mechanical properties in composite samples were obtained from the samples, including 5\% PVAc and 15\% jute fibers. It was determined that an increase in the amount of fibers and binder content of the samples brought an increase in the density and flexural strength values. On the other hand, it was detected that the water absorption ratio increased as the fiber amount increased, and the water absorption amount decreased as the binder concentration increased in the samples. In cases where the binder concentration exceeds $30 \%$, the physical and mechanical properties of the composite samples decrease as the amount of PVAc increases. This decrease is explained by the dependence of the composite material properties on resin properties. Zeleke and Rotich [35] produced composite false ceiling material with sawdust, banana fiber and PVAc resin in their study. Computer software was used for producing samples, and a ratio of $40 \%$ sawdust, $40 \%$ PVAc resin and $20 \%$ fiber was determined as the most suitable material rates. The tensile and flexural strength of the composite samples prepared at these rates were determined as $12.54 \mathrm{MPa}$ and $5.13 \mathrm{MPa}$, respectively. The tensile and flexural strength values of the composite samples showed an increase as the sawdust, fiber, and resin amount increased up to the most suitable rates in the mixture. However, a decrease in the tensile and flexural strength values of the composite samples was observed in the case of using more sawdust, fiber and resin more than the most suitable rates in the production of the samples. As a result, it was mentioned that the developed composite material was environmentally friendly and could be used as ceiling board material.

The purpose of this study was to investigate novelly processing of polymer wood composite material from pine cone and the binder of phenol formaldehyde/PVAc/molasses and improvement of its 
properties. In this study, first time, pine cone and sugar beet molasses were used together as reinforced and binder materials, respectively. Furthermore, the most suitable production parameters for composite samples according to flexural strength were determined. The effect of $\mathrm{f} / \mathrm{b}$ ratio, molasses ratio, molding pressure temperature, molding pressure, particle size, molding pressure time, phenol formaldehyde ratio and hemp fiber ratio production parameters on the production of composite sample was examined.

Phenol formaldehyde resin was used to decrease the water absorption of the composite samples and to protect them against insect attacks. Furthermore, waste colemanite was added to the sample mixtures at different rates in order to develop the nonflammability property of the composite samples.

\section{Material And Methods}

\section{Material}

Pine cone (Pinus Pinea) material was used as the filler material in this study. Pine cone was collected manually in the pine forest in Turkey, Eskişehir. The density of ground pine cone material was detected as $0.43 \mathrm{~g} / \mathrm{cm}^{3}$.

Hemp fiber was provided from Kastamonu, Turkey and cut at the laboratory at a length of $\sim 6 \mathrm{~cm}$. Molasses, which is a waste material provided by Eskişehir Sugar Factory in Turkey, was used as a binder in producing composite material. The chemical properties of the molasses material are shown in Table 1.

Table 1

Chemical properties of molasses (wt.\%)

\begin{tabular}{|llllllllll|}
\hline $\begin{array}{l}\text { Brix } \\
(\%)\end{array}$ & $\begin{array}{l}\text { Density } \\
\left(\mathbf{g} / \mathrm{cm}^{3}\right)\end{array}$ & $\begin{array}{l}\text { Purity } \\
(\%)\end{array}$ & $\begin{array}{l}\text { Sucrose } \\
(\%)\end{array}$ & $\begin{array}{l}\text { Invert } \\
\text { sugar } \\
(\%)\end{array}$ & pH & $\begin{array}{l}\text { Ash } \\
(\%)\end{array}$ & $\begin{array}{l}\text { Betaine } \\
(\%)\end{array}$ & $\begin{array}{l}\text { Raffinose } \\
(\%)\end{array}$ & $\begin{array}{l}\text { Nitrogen } \\
(\%)\end{array}$ \\
\hline 86 & 1.178 & 59 & 52 & 0.09 & 9 & 11.9 & 5 & 1.10 & 1.90 \\
\hline
\end{tabular}

It was used as a PF and PVAc binder material in composite sample production. PF is Polifen47, which is a product of Polisan Chemical Factory in Kocaeli, Turkey. The physical and chemical properties of PF are shown in Table 2, and the physical and chemical properties of PVAc, which is a product of a glue factory in Eskişehir, Turkey, are shown in Table 3. 
Table 2

Physical and mechanical properties of PF

\begin{tabular}{|ll|}
\hline Appearance & Reddish brown liquid \\
\hline Solid, $(\mathrm{wt} . \%)$ & $46 \sim 48$ \\
\hline Viscosity $\left(\mathrm{cPs}, 20^{\circ} \mathrm{C}\right)$ & $300 \sim 700$ \\
\hline $\mathrm{pH}$ & $10.50 \sim 13.00$ \\
\hline Density $\left(\mathrm{g} / \mathrm{cm}^{3}\right)$ & $1.200 \sim 1.215$ \\
\hline Free formaldehyde $(\%)$ & $<0.1$ \\
\hline Water tolerance & Infinite \\
\hline Flow rate $(\mathrm{sec}, \mathrm{DC} 4)$ & $50 \sim 130$ \\
\hline Gel time $\left(\mathrm{min}, 105^{\circ} \mathrm{C}\right)$ & $10 \sim 20$ \\
\hline
\end{tabular}

Table 3

Physical and mechanical properties of PVAc

\begin{tabular}{|ll|}
\hline Appearance & Milk white \\
\hline Solid, $($ wt. $\%)$ & $\sim 50$ \\
\hline Density $\left(\mathrm{g} / \mathrm{cm}^{3}\right)$ & $1.19 \sim 1.21$ \\
\hline $\mathrm{pH}\left(25^{\circ} \mathrm{C}\right)$ & $3.5 \sim 4$ \\
\hline Chemical formula & $\left(\mathrm{C}_{4} \mathrm{H}_{6} \mathrm{O}_{2}\right)_{\mathrm{n}}$ \\
\hline
\end{tabular}

Waste colemanite was used as a filler material to increase the fire resistance of composite samples. Waste colemanite was provided from tailings dam of Emet Eti Boron Factory located in Kütahya, Turkey. The results of the chemical analysis of waste colemanite are shown in Table 4. 
Table 4

The chemical analysis of

waste colemanite

\begin{tabular}{|ll|}
\hline Compounds & $(w / w) \%$ \\
\hline $\mathrm{SiO}_{2}$ & 45.4 \\
$\mathrm{Al}_{2} \mathrm{O}_{3}$ & 9.71 \\
\hline $\mathrm{MgO}$ & 8.73 \\
\hline $\mathrm{K}_{2} \mathrm{O}$ & 4.31 \\
\hline $\mathrm{CaO}$ & 5.92 \\
\hline $\mathrm{Fe}_{2} \mathrm{O}_{3}$ & 4.71 \\
\hline $\mathrm{B}_{2} \mathrm{O}_{3}$ & 9.31 \\
\hline $\mathrm{P}_{2} \mathrm{O}_{5}$ & 0.16 \\
\hline $\mathrm{SO}_{4}$ & 0.19 \\
\hline $\mathrm{TiO}_{2}$ & 0.60 \\
\hline $\mathrm{SrO}$ & 0.81 \\
\hline Density $\left(\mathrm{g} / \mathrm{cm}^{3}\right)$ & $\sim 2.40$ \\
\hline
\end{tabular}

Sulphuric acid $\left(\mathrm{H}_{2} \mathrm{SO}_{4}\right)$ at a rate of $0.10 \mathrm{ml}$ was added to composite sample mixtures. $\mathrm{H}_{2} \mathrm{SO}_{4}$ density is $1.84 \mathrm{~g} / \mathrm{cm}^{3}$.

\section{Methods}

\section{Sample preparation}

The composite test samples prepared in the laboratory were produced based on various parameters.

Those parameters are, respectively, $\mathrm{f} / \mathrm{b}$, molasses ratio, molding pressure-temperature, molding pressure, particle size, molding pressure time, PF ratio and hemp fiber ratio. The highest flexural strength value of the composite material was detected, and the most suitable production conditions were determined in each parameter. Flexural strength test was selected as it is among the most important properties for wooden and construction materials. Cone, which is used for composite material production, was first ground by a Retsch brand grinder and sieved using $180 \mu \mathrm{m}, 300 \mu \mathrm{m}, 450 \mu \mathrm{m}, 600 \mu \mathrm{m}, 900 \mu \mathrm{m}$ and $1 \mathrm{~mm}$ sieves. All materials which were added to the composite mixture were measured by the precision scale. As a mold of $60 \times 120 \mathrm{~mm}$ is used in composite sample production, the volume of this container was taken into consideration and the net amount of materials added to the composite sample mixture was 
found through trial-and-error. Filler materials and binder materials were stirred by hand in a plastic container for 5 minutes. The binder materials that are added to the initial trial mixtures are $47.5 \%$ PVAc, $47.5 \%$ molasses and $5 \%$ PF by weight. Sample mixtures were poured into a rectangular prismatic steel mold of $60 \times 120 \mathrm{~mm}$, and compression was conducted using Carver brand hot press device. Rectangular prismatic composite samples in sizes of $120 \times 60 \times 7 \mathrm{~mm}$ were obtained as a result of the molding process. The composite samples that were obtained were cured in a drying oven for 24 hours at $70 \pm 2^{\circ} \mathrm{C}$ until they reached a stable weight. After curing, the composite samples that were produced were held in laboratory conditions during the test.

\section{Tests Conducted On Composite Samples}

The mechanical properties of the composite samples were determined based on a three-point flexural strength test. The flexural strength test was conducted using Shimadzu AG-I tester according to European Norm EN 310 [36]. The span length in the flexural strength test is $40 \mathrm{~mm}$, and the crosshead speed is 10 $\mathrm{mm} / \mathrm{min}$. Flexural strength values were determined by taking the arithmetic mean values of six composite samples. Waste colemanite was added instead of the cone to improve the nonflammability property of the composite sample, and the nonflammability property of the sample was determined based on the limit oxygen index ( $\mathrm{LOI}$ ) test. LOI test was conducted by the DYNISCO tester according to ASTM D 2863-19 [37] standard. On the other hand, water absorption and 24 hours thickness swelling values were determined according to EN 317 [38]. Composite test samples were prepared at $50 \times 50 \times 7$ $\mathrm{mm}$, and their sizes were precisely measured using a caliper. Screw withdrawal tests on the composite materials were conducted using Mares test equipment in compliance with EN 320 [39] and EN 13446 [40] standards. A screw with a screw diameter of $4.2 \mathrm{~mm}$, screw length of $38 \mathrm{~mm}$, and screw pitch of $1.4 \mathrm{~mm}$ was used in the screw withdrawal test.

\section{Results And Discussion}

\section{Determining composite material producing parameters}

\section{Filler/binder ratio}

The flexural strength values of the composite samples at different $f / b$ ratios by keeping the number of binder materials fixed are shown in Fig. 1. Upon examining Fig. 1, it can be seen that the highest flexural strength in the samples prepared at $0.25 \mathrm{f} / \mathrm{b}$ ratio by weight was determined as $\sim 6 \mathrm{MPa}$. It was determined that flexural strength values of the samples increased as the cone filler material amount increased up to $0.25 \mathrm{f} / \mathrm{b}$ ratio in the composite sample mixture. However, it was determined that flexural strength values of the samples decreased as the filler material amount increased over $0.25 \mathrm{f} / \mathrm{b}$ ratio in the composite sample mixture. This can be explained as the weakening of bonding between the increased filler particles in the sample mixture and the binder material, of which the amount was kept fixed. 
It was determined that flexural strength increased up to a certain $\mathrm{f} / \mathrm{b}$ ratio in composite sample production (Fig. 1). Choi et al. [41] produced composite material at the ratios of $0.0,0.5,1.0$ and $1.5 \mathrm{f} / \mathrm{b}$ from rice husk and plastic parts and obtained the highest flexural strength value in the composite sample of $1.0 \mathrm{f} / \mathrm{b}$ ratio. Gürü et al. [42] prepared composite boards at $\mathrm{f} / \mathrm{b}$ ratios varying at $0.8 \sim 3.2$ using ground nutshells. The highest flexural strength was obtained as $4.1 \mathrm{MPa}$ in the samples with $\mathrm{f} / \mathrm{b}$ ratio of 2.4 among the composite samples prepared. As it is seen, an increase in the flexural strength up to a certain $\mathrm{f} / \mathrm{b}$ ratio is similar to the literature. Consequently, it was determined that a low-cost composite material that can preserve its dimensional stability could be produced through trial and error by using waste material. As a result of the tests, the most suitable $\mathrm{f} / \mathrm{b}$ ratio was detected as 0.25 , and the calculation was carried out based on the volume of the mold used, and all samples were produced as $150 \mathrm{~g}$. Those samples are formed of the mixture of $30 \mathrm{~g}$ ground pine cone and $120 \mathrm{~g}$ binder. Composite samples were prepared using the determined $0.25 \mathrm{f} / \mathrm{b}$ ratio, and other production parameters were researched in the next step of the study.

\section{Molasses ratio}

The samples were produced using molasses at $25 \%, 30 \%, 35 \%, 40 \%, 45 \%$ ve $47.5 \%$ by weight in substitution for PVAc, which is used as a binder after $0.25 \mathrm{f} / \mathrm{b}$ ratio by weight was determined experimentally in the mixture of composite material. PF was added to the binder mixture at the rate of $5 \%$, and this ratio was kept fixed among all composite samples. The flexural strength values of the composite samples are shown in Fig. 2.

The highest flexural strength in composite samples was determined as 16 MPa in the samples, including molasses up to $35 \%$ by weight (Fig. 2). An increase in the flexural strength by adding molasses up to $35 \%$ in the composite sample can be explained by the binder property of the sugar in molasses [43]. Furthermore, in the case of adding more than $35 \%$ molasses to the sample mixture, a decrease in the amount of PVAc forming cross-link caused flexural strength to decrease. As a result, it was determined that polymer binding PVAc and PF and molasses could be used as a binder experimentally in composite material production. Using molasses led to a decrease in the use of chemical binder material in composite material producing. Thus, the production of a composite material that is both less harmful to human health and more economical could be obtained. It is seen that different organic binders can be used in producing composite materials in the literature [44]. According to the results obtained from the tests, the best molasses ratio in the composite sample mixture was determined as $35 \%$. Accordingly, the molasses/PVAc ratio was calculated as 0.58 by weight. Composite samples were prepared using the determined $0.25 \mathrm{f} / \mathrm{b}$ ratio and $35 \%$ ratio, and other production parameters were reviewed in the next step of the study. An image of the composite sample including molasses is shown in Fig. 3.

\section{Molding pressure temperature}

Composite samples were produced at molding pressure-temperatures ranging from $60 \sim 140{ }^{\circ} \mathrm{C}$, and the flexural strength values of the samples are shown in Fig. 4. According to Fig. 4, the highest flexural strength was determined as $\sim 16 \mathrm{MPa}$ in the samples produced at $100{ }^{\circ} \mathrm{C}$ molding pressure-temperature. 
Accordingly, the molding pressuretemperature at which the highest flexural strength value is obtained, which is among the most important parameters in producing composite samples, was determined. It is observed that the flexural strength values decrease gradually in the samples produced at a temperature higher than this pressure temperature value. The decrease in the flexural strength of the samples produced at high temperature is explained by the deterioration of the polymeric binder material in the sample due to the increase in the molding pressure temperature [45].

Composite materials produced in different pressure-temperatures are seen in the literature. Kusumah et al. [46] produced composite materials at $140 \sim 220^{\circ} \mathrm{C}$ pressure-temperature using waste bagasse and citric acid and detected the highest flexural strength in the samples produced at $200{ }^{\circ} \mathrm{C}$. They determined in the study that there were impairments on the surface of the sample as the pressure-temperature increased. Sahin et al. [47] produced composite materials between $30 \sim 150^{\circ} \mathrm{C}$ molding pressuretemperature using peachnut shell and polymeric binder material and obtained the highest flexural strength value at the samples produced at $120^{\circ} \mathrm{C}$. It was mentioned that high pressure-temperature in sample production caused an impairment in the polymeric binder materials. It is understood that the result of the test in the literature and the results of our test are similar. $100{ }^{\circ} \mathrm{C}$ molding pressure temperature: was taken constant in the sample production following this step.

\section{Molding pressure}

The composite test samples were produced using molding values ranging between $14 \sim 69 \mathrm{~kg} / \mathrm{cm}^{2}$ in order to determine the most suitable molding pressure. The flexural strength values of the composite samples produced using different molding pressure values are shown in Fig. 5 . It is seen that the highest flexural strength value ( 18 MPa) is in the composite samples produced at $49 \mathrm{~kg} / \mathrm{cm}^{2}$ and the flexural strength decreased following this value upon reviewing Fig. 5 . This decrease can be explained by the leak of the binder material out of the mold relatively during the application of high pressure temperature at sample production. On the other side, a low flexural strength value in the samples produced using low molding pressure can be explained by less compression of these samples; therefore, they have a void structure.

It is seen that the test results obtained are similar to the studies in which the composite samples are produced using different molding pressure $[47,48] .49 \mathrm{~kg} / \mathrm{cm}^{2}$ molding pressure was taken as constant in the sample production following this step.

\section{Particle size}

The effect of using ground cone filler material at an average particle size of $240 \mu \mathrm{m}, 375 \mu \mathrm{m}, 525 \mu \mathrm{m}$, $750 \mu \mathrm{m}$ and $950 \mu \mathrm{m}$ to the flexural strength of composite samples is shown in Fig. 6. Upon reviewing Fig. 6 , the highest and the lowest flexural strength values were obtained in the samples produced with a filler material with the mean particle size of $240 \mu \mathrm{m}$ and $950 \mu \mathrm{m}$, respectively. According to these results, the flexural strength values of the samples increase as the mean particle size of the filler material decrease in the composite sample production. Such an increase in the flexural strength can be explained by the fact 
that the surface area of the filler material with a smaller mean particle size is the largest. Therefore a stronger binding occurs between the binder material and the filler material particles as the surface area of the filler material particles increase.

Li et al. [49] expressed that the adhesive bond between particles and bonding resin decreased due to an increase in the rough-grained particles within the composite samples which they produced using rice straw at various sizes, and the decrease in the particle surface area negatively affected the flexural strength of the samples. Khazaeian et al. [50] detected the highest flexural strength value among the composite samples that they produced using sorghum straw at samples with finer particles and the lowest flexural strength value at samples with coarser particle size. The results in this literature are similar to the results of our study. According to this result, the mean particle size ( $d$ ) in the sample production was taken as $240 \mu \mathrm{m}$ constant.

\section{Molding pressure time}

The flexural strength values of the composite samples produced at different molding pressure times by keeping the pressure-temperature and molding pressure constant are shown in Fig. 7. As it is seen in Fig. 7 , it was detected that the flexural strength values of the samples increased gradually up to 25 minutes, and the flexural strength remained fixed at 30 minutes of molding pressure time. Furthermore, it was detected that the flexural strength values of the samples produced at 20, 25 and 30 minutes molding pressure times were quite close to each other (Fig. 7). This result can be explained by the completion of the chemical reaction of the binder material following 20 minutes of molding pressure time. On the other hand, the molding pressure time in the composite sample production was selected as 20 minutes in order to provide time and energy saving in terms of engineering in the composite sample as there is an insignificant difference such as $\sim 0.5 \mathrm{MPa}$ between the flexural strength value obtained in 20 minute molding pressure time and 30 minute.

Kusumah et al. [46] detected that the highest and lowest flexural strength values at the samples with 10 minutes and 2 minutes respectively among the composite samples, which they produced at 2 15 minute molding pressure times. Wang and Sun [51] determined that the tensile strength values of the samples produced with molding pressure time longer than 8 minutes did not change relatively among the composite samples which they prepared at $6 \sim 12$ minutes of molding pressure times. The results are seen similar to each other upon comparing the test results obtained in the literature with these results. The most suitable molding pressure time was selected as 20 minutes in the composite sample production, taking the obtained result into consideration, and this time was taken constant in other production steps.

\section{Phenol formaldehyde ratio}

Composite test samples were produced by holding molasses/PVAc ratio fixed as 0.58 in binder mixtures. In the composite sample production, the effect of using PF at different ratios in the binder mixture on the flexural strength was researched at this step. The flexural strength values of the composite samples prepared using PF at various rates between $5 \sim 35 \%$ by weight are shown in Fig. 8. Upon viewing Fig. 8, it 
was detected that the flexural strength values of the samples increased in cases where the PF amount in the binder mixture increased up to $20 \%$ in the binder mixture. The increase in the flexural strength can be explained by the cross-link formed by PF used in the sample production with filler material particles [20]. In any case, it was detected that the flexural strength values of the samples significantly decreased when the PF ratio was added to the binder material mixture over $20 \%$. This decrease can be explained by the increase in the leak of the binder mixture out of the mold relatively as the sample mixtures become more fluid as the PF ratio increases.

Ayrilmis et al. [4] expressed that the mechanical strength of the samples increased as the PF ratio increased in the composite samples produced by adding PF at the rates of $8 \sim 12 \%$ by weight.

Viswanathan and Gothandapani [30] detected the most suitable PF ratio as $20 \%$ according to the flexural strength between the composite samples which they prepared using PF at the ratios of $12 \%, 16 \%$ and

$20 \%$ by weight. In the same study, it was observed that the flexural strength of the samples increased as the PF ratio increased in the sample production. This result in the literature and the results obtained from the tests are similar. The highest flexural strength value was detected as $\sim 22 \mathrm{MPa}$ in the composite samples produced, adding PF at a $20 \%$ ratio to the binder mixture (Fig. 8). Following this step, other production parameters were determined by taking a $20 \% \mathrm{FF}$ ratio fixed in the composite sample production.

\section{Hemp fiber ratio}

Waste industrial hemp fibers were added to the sample mixtures while preparing the sample in order to increase the mechanical strength of the composite samples. The flexural strength values of the composite samples produced by adding waste hemp fibers at different ratios are shown in Fig. 9. The composite samples were produced using waste hemp fiber at different ratios between $0 \sim 1.5 \%$ by weight according to the binder amount. Upon reviewing Fig. 9, the highest flexural strength value was detected as $\sim 24 \mathrm{MPa}$ in the hemp fiber samples of $0.5 \%$, and the flexural strength value decreased gradually as fibers over $0.5 \%$ were added. This decrease can be explained by the voids formed around the fiber. It is stated that the mechanical strength decreases due to the increase in the number of voids as the amount of fibers increases in the sample mixture [52]. On the other side, producing a more economical composite material is aimed by using waste hemp fiber in the sample production.

Sahin et al. [47] determined that tensile strength value increased up to a ratio of $15 \%$ in the composite with tea leaf at various ratios between $0 \sim 22 \%$, and the tensile strength value of the samples decreased after this ratio. Narciso et al. [53] expressed that the flexural strength values of the samples gradually decreased as the coconut fiber ratio increased in composite samples. The increase in the amount of voids in parallel to the increase in the fiber amount in the sample mixture in our study was also detected in this study. In this regard, the results obtained are similar to the literature. According to this result, the most suitable hemp fiber ratio in the samples producing were detected as $0.5 \%$, and waste hemp fiber at the ratio of $0.5 \%$ (fixed) was added to all sample mixtures produced as the highest flexural strength was obtained. 
On the other side, according to the flexural strength classification of the particleboards having $6 \sim 13 \mathrm{~mm}$ thickness stated in EN 312 [54] standard, P1 (General use) for $\geq 10.5 \mathrm{MPa}, \mathrm{P} 2$ (interior equipment) for $\geq$ $11 \mathrm{MPa}, \mathrm{P} 3$ (Non load bearing-Wet) for $\geq 15 \mathrm{MPa}$, P4 (Load bearing-Dry) for $\geq 16 \mathrm{MPa}$ and P5 (Load bearing-Wet) for $\geq 18 \mathrm{MPa}$ is accepted. As it is seen, the composite samples with $0.5 \%$ waste hemp fiber in which the highest flexural strength is obtained meet the flexural strength criteria of P1, P2, P3, P4 and P5 type boards in EN 312 completely [54]. According to these results, it can be said that composite samples with $0.5 \%$ waste composite samples can be used as 5 different types of boards. Furthermore, it is seen in Fig. 9 that the lowest flexural strength value ( 14 MPa) is obtained in the composite samples in which the most hemp fiber is used. Accordingly, even the samples with $1.5 \%$ hemp fiber are included with the $\mathrm{P} 1$ and $\mathrm{P} 2$ classes stated in this standard.

\section{Properties of the Composite Samples}

\section{Water absorption and thickness swelling}

The water absorption and thickness swelling values of the composite samples produced with waste fibers at different ratios were detected after they were immersed in water for 24 hours. The thickness swelling values of the samples with hemp fibers of $0 \sim 1.5 \%$ to the binder weight are shown in Fig. 10, and water absorption values are shown in Fig. 11. As it is seen, it was detected that the thickness swelling values of the samples increased as the amount of fiber increased in the composite sample mixture. The lowest and the highest thickness swelling values were obtained in the sample without fibers and the sample with $1.5 \%$ hemp fiber, respectively.

The water absorption values of the samples increase as the hemp fiber ratio increase in the composite sample (Fig. 11). As it is seen, the graphic curves obtained in Fig. 10 and Fig. 11 are similar.

Insert approx. here $\ll<$ Fig. 11 Water absorption values according to hemp fiber ratio (Production conditions: $\mathrm{f} / \mathrm{b}: 0.25$, binder weight: $120 \mathrm{~g}$, molding temperature pressure: $100^{\circ} \mathrm{C}$, molding pressure: 49 $\mathrm{kg} / \mathrm{cm}^{2}, \mathrm{~d}: 240 \mu \mathrm{m}$, molding pressure time: 20 minutes) >>>

The increase in thickness swelling and water absorption values occurring as the fiber ratio increases in the composite samples can be explained by water absorption of the fibers and water-filled in the voids formed around the fiber. The result that is obtained is similar to the test results obtained by Ashori and Sheshmani [55]. According to EN 312 standard [54], the 24 hour thickness swelling limit values of the composite boards with $6 \sim 13 \mathrm{~mm}$ thickness are stated as maximum $17 \%, 16 \%$ and $11 \%$ for P3, P4 and $P 5$, respectively. Accordingly, it is seen that the composite samples with $0.5 \%$ waste hemp fibers in which the highest flexural strength was obtained are in compliance with the thickness swelling values of P3, P4 and P5 classes.

\section{Limit oxygen index}


Limit oxygen index (LOI) is the minimum oxygen concentration necessary for a material to continue to burn in inflames [56]. Both the LOI level value and the fire resistance of the material increase by using fire retardant additive in the material mixture [57]. Waste colemanite at the rates of $0 \%, 5 \%, 10 \%, 20 \%, 40 \%$ and $50 \%$ instead of cone filler in the sample mixture to improve the nonflammability property of the composite in this study. LOI chart of the samples produced by adding waste colemanite is shown in Fig. 12. It was detected that the LOI level values of the samples increase as the waste colemanite amount in the composite sample mixture increases. This matter can be explained as waste colemanite used in the mixture having nonflammability property.

In literature, it is found that expandable graphite use in sawdust and polypropylene based composite samples and the natural zeolite used in producing medium density fiberboards increase LOI values of the samples $[58,59]$. LOI test results obtained in our study and the results obtained in the literature are coherent. On the other side, the flexural strength values of the samples in which waste colemanite is used are shown in Fig. 13.

Upon reviewing Fig. 13, it is seen that the flexural strength values of the samples decrease as the waste colemanite amount in the composite sample mixture increases. This decrease can be explained by a weak bond between the binder material and the waste colemanite. The highest and the lowest flexural strength values between the composite samples were obtained in the mixtures in which $5 \%(\sim 19 \mathrm{MPa})$ and $50 \%(8.5 \mathrm{MPa})$ waste colemanite were used, respectively. Based on these results, in compliance with EN 312 standard [54], the samples with 5\% waste colemanite meet P1, P2, P3, P4 and P5 particle board flexural strength values, the samples with $10 \%$ waste colemanite meet P1, P2, P3 and P4 class particle board flexural strength values and the samples with $20 \%$ waste colemanite meet P1, P2 and P3 class particleboard flexural strength values. In the composite sample mixtures, including the addition of granulated glass between $5 \sim 50 \%$, it was detected that the LOI level increased as the granulated glass amount increased, but tensile strength decreased [47]. This result in the literature and the results obtained are coherent.

\section{Screw withdrawal strength}

Screw withdrawal strength is significantly important for installing boards and other components in the furniture and construction industry [60]. The screw withdrawal strength values of the composite samples produced by adding $0 \sim 50 \%$ waste colemanite are shown in Fig. 14. Upon reviewing Fig. 14, it is seen that the screw withdrawal strength values of the samples decrease analogous to the flexural strength values as the waste colemanite amount in the composite sample mixture increases. This decrease can involve a weak bond between the binder material and the waste colemanite. The highest and the lowest screw withdrawal strength between the composite samples were detected in the samples in which $5 \%(\sim 45$ $\mathrm{N} / \mathrm{mm})$ and $50 \%(\sim 21 \mathrm{~N} / \mathrm{mm})$ waste colemanite were used, respectively.

It was determined that the screw withdrawal strength decreased in parallel to the decrease in the flexural strength value as the amount of vine pruning increases in the sample upon using vine pruning wastes at the ratios of $0 \sim 100 \%$ instead of sawdust in the composite material production [61]. Similar to this study, 
in another research, it was detected that the flexural strength and screw withdrawal strength values decrease when sawdust is substituted with $50 \%$ rice husk and $50 \%$ bamboo in the composite sample production [62]. As can be seen, it is understood that there is an analogy between flexural strength and screw withdrawal values in the composite samples. These results in the literature and the results that we obtained in our study are coherent.

In the study of bringing environmentally friendly waste material to the economy, the most suitable production parameter values obtained from the test results are stated in Table 5.

Pirayesh et al. [7] stated that the flexural strength value of the composite boards produced using walnut shell up to $20 \%$ under $25 \mathrm{~kg} / \mathrm{mm}^{2}$ pressure and at $180{ }^{\circ} \mathrm{C}$ pressure temperature was $\sim 14 \mathrm{MPa}$, and they stated that the boards could be used for general use and as interior equipment. Biswas et al. [63] detected that the flexural strength values of the composite boards produced using bamboo waste under 3.5 $\mathrm{N} / \mathrm{mm}^{2}$ pressure and $140{ }^{\circ} \mathrm{C}$ pressure-temperature was $15.7 \sim 17.7 \mathrm{~N} / \mathrm{mm}^{2}$ and their water absorption values were $45 \sim 48 \%$. In this study, the physical and mechanical test results of the composite materials produced according to the production parameters summarized in Table 5 are generally in compliance with the literature.

\section{Conclusions}

Composite material production using cone, which is a plant waste; molasses, which is a sugar factory waste; waste colemanite, industrial hemp fiber, PVAc and PF is examined in this study. The most suitable composite material production parameter values, in which the highest flexural strength value was obtained, were detected in the study. These parameter values were determined as $0.25 \mathrm{f} / \mathrm{b}, 35 \%$ molasses ratio, $100^{\circ} \mathrm{C}$ molding pressure-temperature, $49 \mathrm{~kg} / \mathrm{cm}^{2}$ molding pressure, 20 minutes molding pressure time, $240 \mu \mathrm{m}$ mean particle size, $\% 20 \mathrm{PF}$ ratio and $0.5 \%$ hemp fiber ratio. The results that are obtained from composite materials produced according to these parameter values can be summarized as follows:

1. The flexure strength values of the samples decrease as the pine cone filler material amount increases in the composite sample production.

2. Composite material production with dimensional stability was performed using molasses. Therefore it was detected that the waste molasses could be used as a binder together with PVAc and PF in the composite material production.

3. The flexural strength values of the samples increase as the molding pressure temperature increases up to $100^{\circ} \mathrm{C}$ in composite sample production. On the other hand, flexural strength values of the samples decrease due to the deterioration of the binder materials as the molding pressure temperature exceeds $100^{\circ} \mathrm{C}$.

4. During the molding process of the samples, the flexural strength values of the samples increase up to $49 \mathrm{~kg} / \mathrm{cm}^{2}$ mold pressure. Furthermore, the binder material leaks out of the mold when the molding pressure exceeds $49 \mathrm{~kg} / \mathrm{cm}^{2}$ in the sample production, and accordingly, the flexural strength values of the samples decrease. 
5. The flexural strength values of the samples increase as the mean particle size decrease in the composite sample production. The highest flexural strength value was obtained from the composite samples having the smallest mean particle size value.

6. The flexural strength values of the samples increase when the molding pressure time in the composite material production is applied for about 20 minutes.

7. Adding PF to the binder mixture up to $20 \%$ increases the flexural strength values of the composite samples. However, the sample mixture becomes more fluidized, and leaks from the mold increase and the flexure strength values of the samples decrease in case of PF over $20 \%$ is added.

8. Using waste hemp fiber up to $0.5 \%$ in composite material producing increases the flexure strength values of the samples. The flexure strength decreases due to the voids occurring around the fiber when this ratio is exceeded.

9. Water absorption and thickness swelling values also increase when the amount of fiber increase in the samples as hemp fiber absorbs water and water fills the voids occurring around the fibers. The water absorption and thickness swelling values obtained in the composite samples are in compliance with EN 312 standard.

10. LOI level values of the samples increase as the waste colemanite amount increase in the composite materials. According to this result, colemanite improves the non-flammability property of the composite material.

11. The flexural strength values of the samples decrease as the amount of waste colemanite increases in the composite material mixture. The flexural strength values obtained by using waste colemanite up to $10 \%$ in the samples are in compliance with P1, P2, P3 and P4 classes stated in EN 312 standard.

12. The screw withdrawal strength of the samples decreases as the waste colemanite use ratio increases in the composite material mixture.

As a result, a cheaper composite material that is less harmful to human health was produced using plant wastes such as pine cone, industrial hemp fiber and molasses and waste colemanite. Through using the wastes in composite material production, it can be provided to bring in the wastes to economy by recycling, to decrease the use of woods and hence to protect forests and abating environmental pollution through using those wastes in composite material producing. In this study, it is stipulated that the free formaldehyde release of the produced composite material would remain at a very low level, and the composite material that we produced in the laboratory would be used in interior spaces as UF is not used as a binder as different from other studies. It can be proposed to use the composite material produced as an environmentally friendly construction material for exterior and interior construction materials such as roof and wall coating, wall interior surface coating, concrete form material, floor coating, office divide element, roof panel, board, pallet, pergola manufacturing.

\section{Declarations}

\section{Declaration of Competing Interest}


The authors declare that they have no known competing financial interests or personal relationships that could have appeared to influence the work reported in this paper.

\section{Acknowledgements}

This research did not receive any specific grant from funding agencies in the public, commercial, or notfor-profit sectors.

\section{References}

1. Cai Z, In: Nicolais L, Borzacchiello A (Ed) Wood-based composite board Wiley Encyclopedia of Composites, 2012;1-11, Wiley Online Library, USA. https://doi.org/10.1002/9781118097298.weoc262

2. Islam MA, Alam MR, Hannan MO (2012) Multiresponse optimization based on statistical response surface methodology and desirability function for the production of particleboard. Compos Part B: Eng 43(3):861-868. https://doi.org/10.1016/j.compositesb.2011.11.033

3. Baskaran M, Hashim R, Sulaiman O, Hiziroglu S, Sato M, Sugimoto T (2015) Optimization of press temperature and time for binderless particleboard manufactured from oil palm trunk biomass at different thickness levels. Mater Today Commun 3:87-

95. https://doi.org/10.1016/j.mtcomm.2015.04.005

4. Ayrilmis N, Kwon JH, Han TH (2012) Effect of resin type and content on properties of composite particleboard made of a mixture of wood and rice husk. Int J Adhes Adhes 38:79-83. https://doi.org/10.1016/j.ijadhadh.2012.04.008

5. Guntekin E, Karakus B (2008) Feasibility of using eggplant (Solanum melongena) stalks in the production of experimental particleboard. Ind Crops Prod 27(3):354-

358. https://doi.org/10.1016/j.indcrop.2007.12.003

6. Ndazi B, Tesha JV, Bisanda ET (2006) Some opportunities and challenges of producing biocomposites from non-wood residues. J Mater Sci 41(21):6984-

6990. https://doi.org/10.1007/s10853-006-0216-3

7. Pirayesh H, Khazaeian A, Tabarsa T. (2012) The potential for using walnut (Juglans regia L.) shell as a raw material for wood-based particleboard manufacturing. Compos Part B: Eng 43(8):32763280. https://doi.org/10.1016/j.compositesb.2012.02.016

8. Keskin H, Kucuktuvek M, Guru M (2015) The potential of poppy (Papaver somniferum Linnaeus) husk for manufacturing wood-based particleboards. Constr Build Mater 95:224231. https://doi.org/10.1016/j.conbuildmat.2015.07.160

9. Bekalo SA, Reinhardt HW (2010) Fibers of coffee husk and hulls for the production of particleboard. Mater Struct 43(8):1049-1060. https://doi.org/10.1617/s11527-009-9565-0

10. Fiorelli J, Curtolo DD, Barrero NG, Savastano Jr H, Pallone EMDJA, Johnson R (2012) Particulate composite based on coconut fiber and castor oil polyurethane adhesive: An eco-efficient product. Ind 
Crops Prod 40:69-75. https://doi.org/10.1016/j.indcrop.2012.02.033

11. Azizi K, Tabarsa T, Ashori A (2011) Performance characterizations of particleboards made with wheat straw and waste veneer splinters. Compos Part B: Eng 42(7):20852089. https://doi.org/10.1016/j.compositesb.2011.04.002

12. Batiancela MA, Acda MN, Cabangon RJ (2014) Particleboard from waste tea leaves and wood particles. J Compos Mater 48(8):911-916. https://doi.org/10.1177/0021998313480196

13. Acda MN, Cabangon RJ (2013) Termite resistance and physico-mechanical properties of particleboard using waste tobacco stalk and wood particles. Int Biodeterior Biodegrad 85:354358. https://doi.org/10.1016/j.ibiod.2013.08.019

14. Khanjanzadeh H, Bahmani AA, Rafighi A, Tabarsa $T$ (2012) Utilization of bio-waste cotton (Gossypium hirsutum L.) stalks and underutilized paulownia (Paulownia fortunie) in wood-based composite particleboard. Afr J Biotechnol 11(31):8045-8050. Doi: 10.5897/AJB12.288

15. Akinyemi AB, Afolayan JO, Oluwatobi EO (2016) Some properties of composite corn cob and sawdust particle boards. Constr Build Mater 127:436-

441. https://doi.org/10.1016/j.conbuildmat.2016.10.040

16. Sassoni E, Manzi S, Motori A, Montecchi M, Canti M (2014) Novel sustainable hemp-based composites for application in the building industry: Physical, thermal and mechanical characterization. Energ Buildings 77:219-226. https://doi.org/10.1016/j.enbuild.2014.03.033

17. Kaiser C, Cassady C, Ernst M (2015) Industrial hemp production. Central for Crop. Diversification, University of Kentucky, 27:101-106.

18. Anderson E, Baas D, Thelen M, Burns E, Chilvers M, Thelen K... \& Wilke B (2019) Industrial hemp production in Michigan. Michigan State University, USD.

19. Zhao H, Xiong H, Chen J (2021) Regional comparison and strategy recommendations of industrial hemp in China based on a SWOT analysis. Sustainability 13(11):6419. https://doi.org/10.3390/su13116419

20. Conner AH (2001) Wood: adhesives. Encyclopedia of materials: science and technology. Amsterdam; New York: Elsevier Science, Ltd., c2001.

21. Nielsen GD, Larsen ST, Wolkoff P (2017) Re-evaluation of the WHO (2010) formaldehyde indoor air quality guideline for cancer risk assessment. Arch Toxicol 91(1):35-

61. https://doi.org/10.1007/s00204-016-1733-8

22. Gürü M, Atar M, Yıldıım R (2008) Production of polymer matrix composite particleboard from walnut shell and improvement of its requirements. Mater Des 29(1):284-

287. https://doi.org/10.1016/j.matdes.2006.10.023

23. Kozlowski R, Mieleniak B, Fiedorow R, Bujnowicz K. (2005) Light rigid fire blockers. Compos Part A: Applied Science and Manufacturing 36(8):10471054. https://doi.org/10.1016/j.compositesa.2004.11.003

24. Kozlowski R, Mieleniak B, Helwig M, Przepiera A (1999) Flame resistant lignocellulosic-mineral composite particleboards. Polymer Degradation and Stability 64(3):523- 
528. https://doi.org/10.1016/S0141-3910(98)00145-1

25. Gür A (2007) Dissolution mechanism of colemanite in sulphuric acid solutions. Korean J Chem Eng 24(4):588-591. https://doi.org/10.1007/s11814-007-0007-9

26. Tunç M, Kocakerim MM, Küçük Ö, Aluz M (2007) Dissolution of colemanite in (NH4)2SO4 solutions. Korean J Chem Eng 24(1):55-59. https://doi.org/10.1007/s11814-007-5009-0

27. Sevim UK, Ozturk M, Bankir MB, Aydin U (2017) Utilization of colemanite waste in concrete design. International Journal of Advanced Engineering Research and Science 4(12):237344. https://dx.doi.org/10.22161/ijaers.4.12.25

28. Hubert $\mathrm{O}$ (2006) The molasses, Fermentation Technologist institat zucker industrie Berlin (Germany), 101(1):8-38.

29. Weifeng LI, Suhua MA, Shengbiao Z, Xiaodong S (2014) Physical and chemical studies on cement containing sugarcane molasses. J Therm Anal Calorim 118(1):83-

91. https://doi.org/10.1007/s10973-014-3947-4

30. Viswanathan R, Gothandapani L. (1999) Optimum process variables for the production of coir pith particle board. J Agric Engng Res 74(4):331-337. https://doi.org/10.1006/jaer.1999.0470

31. Kim S, Kim HJ (2005) Effect of addition of polyvinyl acetate to melamine-formaldehyde resin on the adhesion and formaldehyde emission in engineered flooring. Int J Adhes Adhes 25(5):456461. https://doi.org/10.1016/j.ijadhadh.2005.01.001

32. Xian-Qing X, Wenting Q, Lu F, Zhihui W, Feng W, Min Z (2016) Producing process for veneer decorative straw particleboards. Wood Research 61(3):465-474.

33. Gürü M, Karabulut AF, Aydın MY, Bilici I (2015) Processing of fireproof and high temperature durable particleboard from rice husk. High Temp Mater Proc 34(6):599-604. Doi: 10.1515/htmp-2014-0092

34. Tigabe S, Atalie D, Gideon RK (2021) Physical properties characterization of polyvinyl acetate composite reinforced with jute fibers filled with rice husk and sawdust. J Natural Fibers 1-

12. https://doi.org/10.1080/15440478.2021.1902899

35. Zeleke Y, Rotich GK (2021) Design and development of false ceiling board using polyvinyl acetate (PVAc) composite reinforced with false banana fibres and filled with sawdust. Int J Polym Sci 110. https://doi.org/10.1155/2021/5542329

36. European Norm (1993) EN 310 Wood based panels, determination of modulus of elasticity in bending and bending strength. European Committee for Standardization.

37. ASTM 2863-19 (2019) Standard test method for measuring the minimum oxygen concentration to support candle-like combustion of plastics (Oxygen Index), United States.

38. European Norm (1993) EN 317 Particleboards and fibreboards determination of swelling in thickness after immersion in water. European Committee for Standardization.

39. European Norm (2011) EN 320 Particleboards and fibreboards - Determination of resistance to axial withdrawal of screws. European Committee for Standardization. 
40. European Norm (2002) EN 13446 Wood - based panels -Determination of withdrawal capacity of fasteners. European Committee for Standardization.

41. Choi NW, Mori I, Ohama Y (2006) Development of rice husks-plastics composites for building materials. Waste Manage 26(2):189-194. https://doi.org/10.1016/j.wasman.2005.05.008

42. Gürü M, Aruntaş Y, Tüzün FN, Bilici I (2009) Processing of urea-formaldehyde-based particleboard from hazelnut shell and improvement of its fire and water resistance. Fire Mater: An Int J 33(8):413419. https://doi.org/10.1002/fam.1011

43. Tondi G, Wieland S, Wimmer T, Schnabel T, Petutschnigg A (2012) Starch-sugar synergy in wood adhesion science: basic studies and particleboard production. Eur J Wood Prod 70:271-

278. https://doi.org/10.1007/s00107-011-0553-z

44. Solt P, Konnerth J, Gindl-Altmutter W, Kantner W, Moser J, Mitter R, van Herwijnen HW (2019) Technological performance of formaldehyde-free adhesive alternatives for particleboard industry. Int J Adhes Adhes 94:99-131. https://doi.org/10.1016/j.ijadhadh.2019.04.007

45. Alonso MV, Oliet M, Dominguez JC, Rojo E, Rodriguez F (2011) Thermal degradation of ligninphenol-formaldehyde and phenol-formaldehyde resol resins: structural changes, thermal stability, and kinetics. J Therm Anal Calorim 105(1):349-356. https://doi.org/10.1007/s10973-011-1405-0

46. Kusumah SS, Umemura K, Guswenrivo I, Yoshimura T, Kanayama K (2017) Utilization of sweet sorghum bagasse and citric acid for manufacturing of particleboard II: Influences of pressing temperature and time on particleboard properties. J Wood Sci 63(2):161-

172. https://doi.org/10.1007/s10086-016-1605-0

47. Sahin A, Tasdemir HM, Karabulut AF, Gürü M (2017) Mechanical and thermal properties of particleboard manufactured from waste peachnut shell with glass powder. Arab J Sci Eng 42(4):1559-1568. https://doi.org/10.1007/s13369-017-2427-0

48. Taha I, Elkafafy MS, El Mously H (2018) Potential of utilizing tomato stalk as raw material for particleboards. Ain Shams Eng J 9(4):1457-1464. https://doi.org/10.1016/j.asej.2016.10.003

49. Li X, Cai Z, Winandy JE, Basta AH (2010) Selected properties of particleboard panels manufactured from rice straws of different geometries. Bioresource Technol 101(12):46624666. https://doi.org/10.1016/j.biortech.2010.01.053

50. Khazaeian A, Ashori A, Dizaj MY (2015) Suitability of sorghum stalk fibers for production of particleboard. Carbohyd Polym 120:15-21. https://doi.org/10.1016/j.carbpol.2014.12.001

51. Wang D, Sun XS (2002) Low density particleboard from wheat straw and corn pith. Ind Crops Prod 15(1):43-50. https://doi.org/10.1016/S0926-6690(01)00094-2

52. Chaharmahali M, Tajvidi M, Najafi SK (2008) Mechanical properties of wood plastic composite panels made from waste fiberboard and particleboard. Polym Compos 29(6):606-

610. https://doi.org/10.1002/pc.20434

53. Narciso CRP, Reis AHS, Mendes JF, Nogueira ND, Mendes RF (2021) Potential for the use of coconut husk in the production of medium density particleboard. Waste Biomass Valor 12:16471658. https://doi.org/10.1007/s12649-020-01099-x 
54. European Norm (2010) EN 312 Particleboards specifications. European Committee for Standardization.

55. Ashori A, Sheshmani S (2010) Hybrid composites made from recycled materials: Moisture absorption and thickness swelling behavior. Bioresource Technology 101:4717-

4720. https://doi.org/10.1016/j.biortech.2010.01.060

56. Zhang ZX, Zhang J, Lu BX, Xin ZX, Kang CK, Kim JK (2012) Effect of flame retardants on mechanical properties, flammability and foamability of PP/wood-fiber composites. Compos Part B: Eng 43(2):150-158. https://doi.org/10.1016/j.compositesb.2011.06.020

57. Jiang J, Li J, Hu J, Fan D (2010) Effect of nitrogen phosphorus flame retardants on thermal degradation of wood. Constr Build Mater 24(12):2633-

2637. https://doi.org/10.1016/j.conbuildmat.2010.04.064

58. Bai G, Guo C, Li L (2014) Synergistic effect of intumescent flame retardant and expandable graphite on mechanical and flame-retardant properties of wood flour-polypropylene composites. Constr Build Mater 50:148-153. https://doi.org/10.1016/j.conbuildmat.2013.09.028

59. Çavdar AD (2020) Effect of zeolite as filler in medium density fiberboards bonded with urea formaldehyde and melamine formaldehyde resins. J Build Eng 27:101000. https://doi.org/10.1016/j.jobe.2019.101000

60. Leng W, Hunt JF, Tajvidi M (2017) Screw and nail withdrawal strength and water soak properties of wet-formed cellulose nanofibrils bonded particleboard. BioResources 12(4):7692-7710.

61. Ntalos GA, Grigoriou AH (2002) Characterization and utilisation of vine prunings as a wood substitute for particleboard production. Ind Crops Prod 16(1):59-68. https://doi.org/10.1016/S09266690(02)00008-0

62. Melo RRD, Stangerlin DM, Santana RRC, Pedrosa TD (2014) Physical and mechanical properties of particleboard manufactured from wood, bamboo and rice husk. Mat Res 17(3):682-686. https://doi.org/10.1590/S1516-14392014005000052

63. Biswas D, Bose SK, Hossain MM (2011) Physical and mechanical properties of urea formaldehydebonded particleboard made from bamboo waste. Int J Adhes Adhes 31(2):84-87. https://doi.org/10.1016/j.ijadhadh.2010.11.006

\section{Figures}




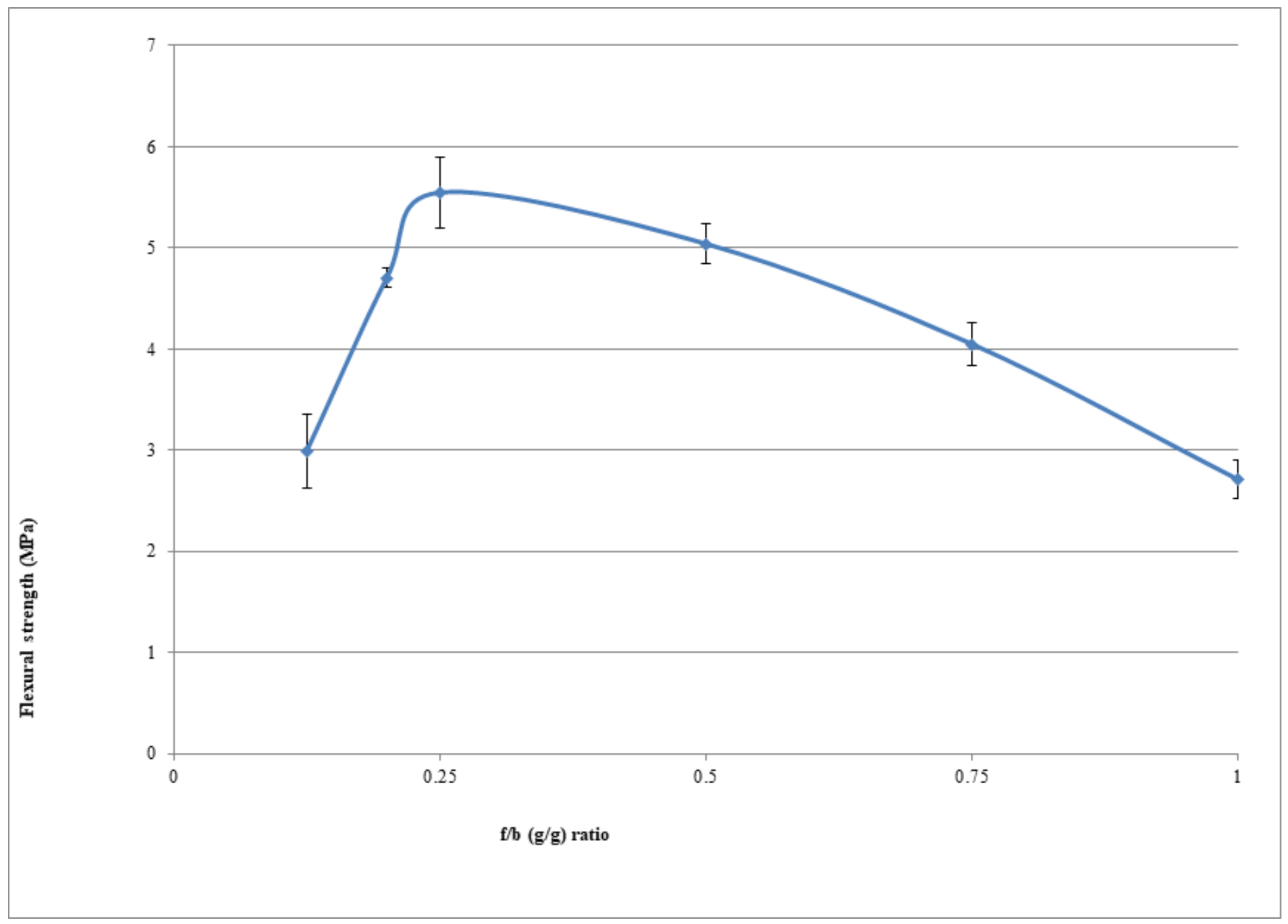

\section{Figure 1}

Determining of $\mathrm{f} / \mathrm{b}$ ratio parameter in composite material production. (Initial production conditions: Binder weight $120 \mathrm{~g}$, molding pressure temperature: $100^{\circ} \mathrm{C}$, molding pressure: $28 \mathrm{~kg} / \mathrm{cm}^{2}$, max. grain size: $1 \mathrm{~mm}$, molding pressure time: 20 minutes) 


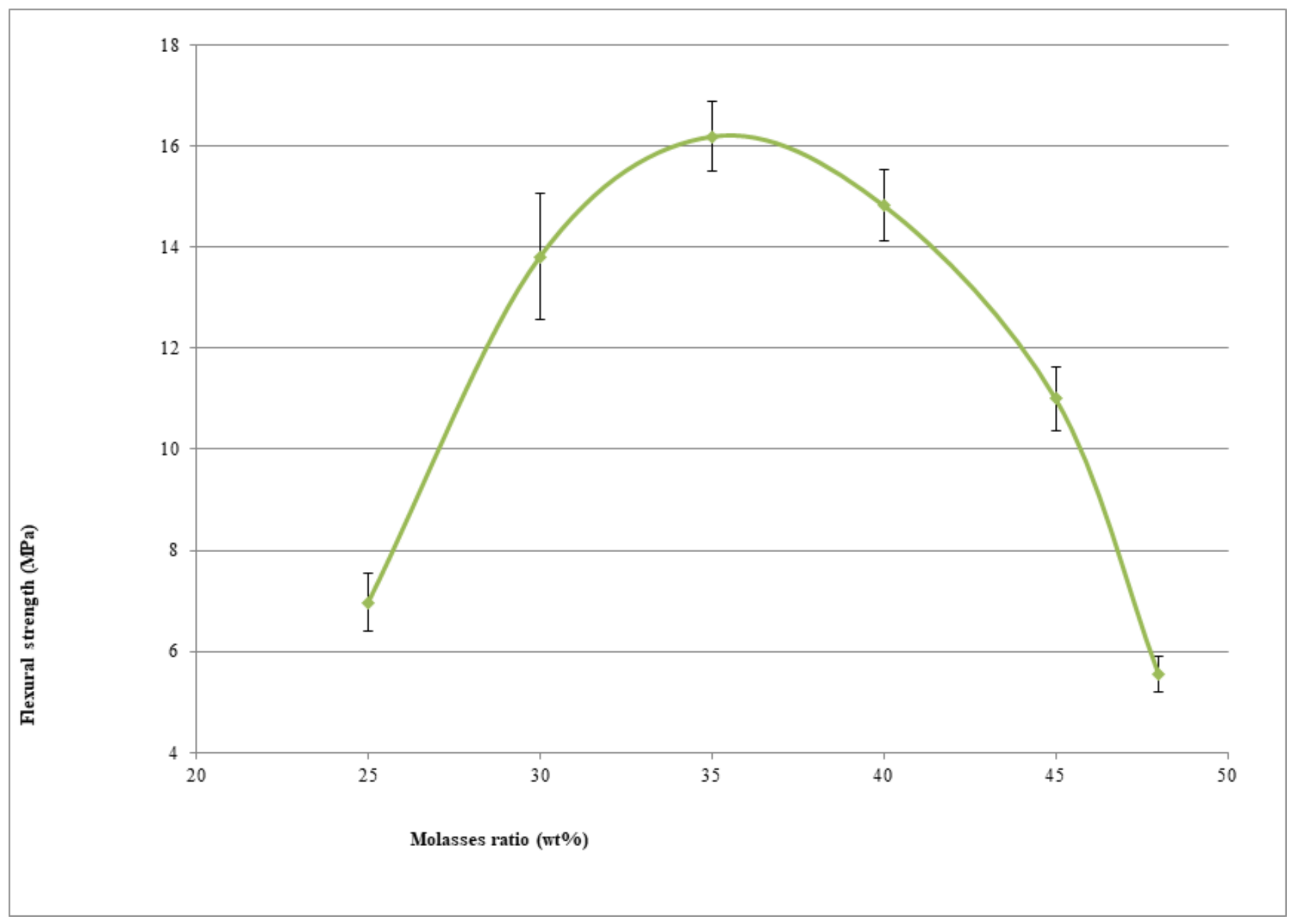

\section{Figure 2}

Determining molasses amount parameter in composite material production (Production conditions: $\mathrm{f} / \mathrm{b}$ : 0.25 , binder weight: $120 \mathrm{~g}$, molding pressure temperature: $100^{\circ} \mathrm{C}$, molding pressure: $28 \mathrm{~kg} / \mathrm{cm}^{2}$, max. grain size: $1 \mathrm{~mm}$, molding pressure time: 20 minutes) 


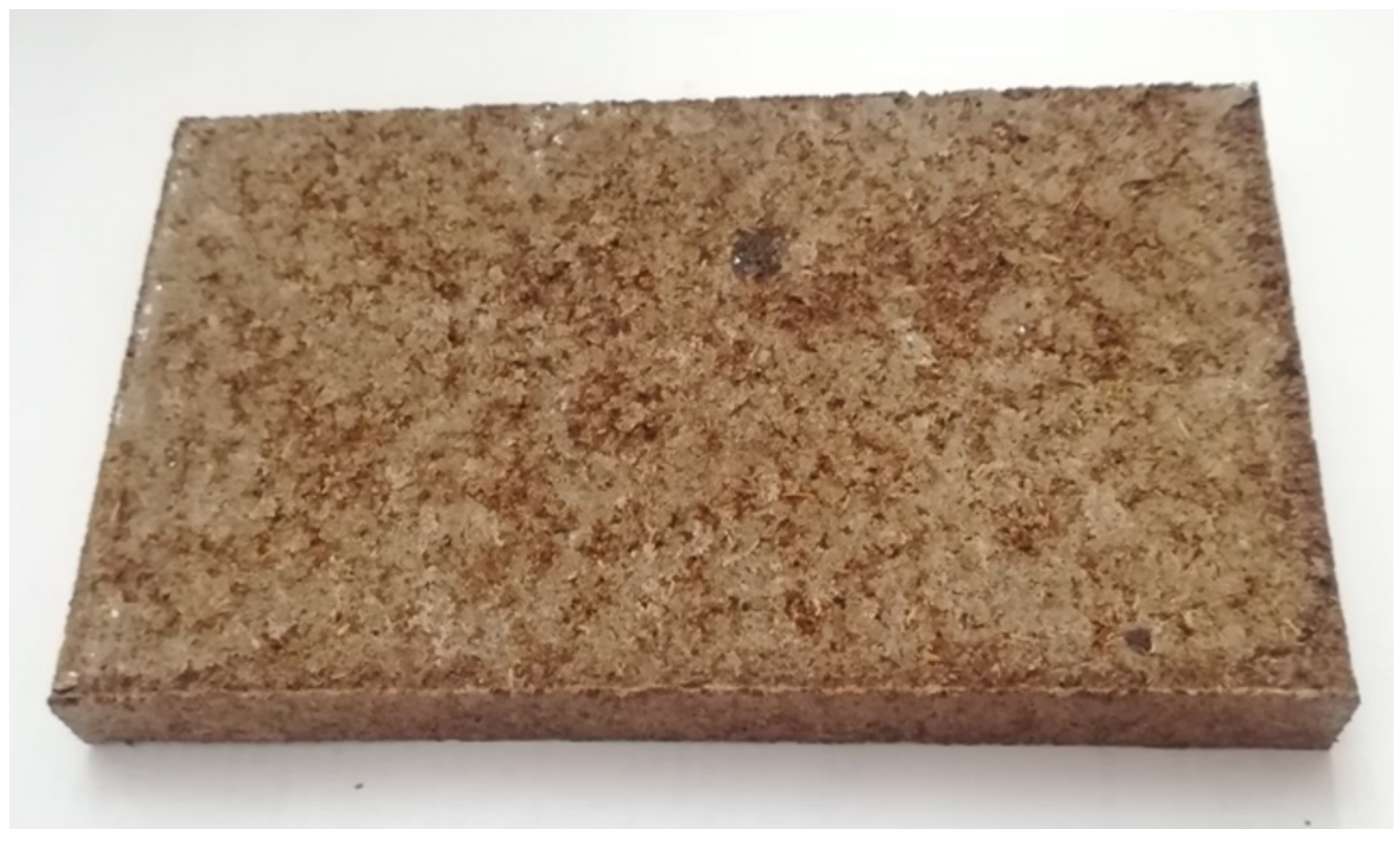

Figure 3

An image of composite sample including molasses 


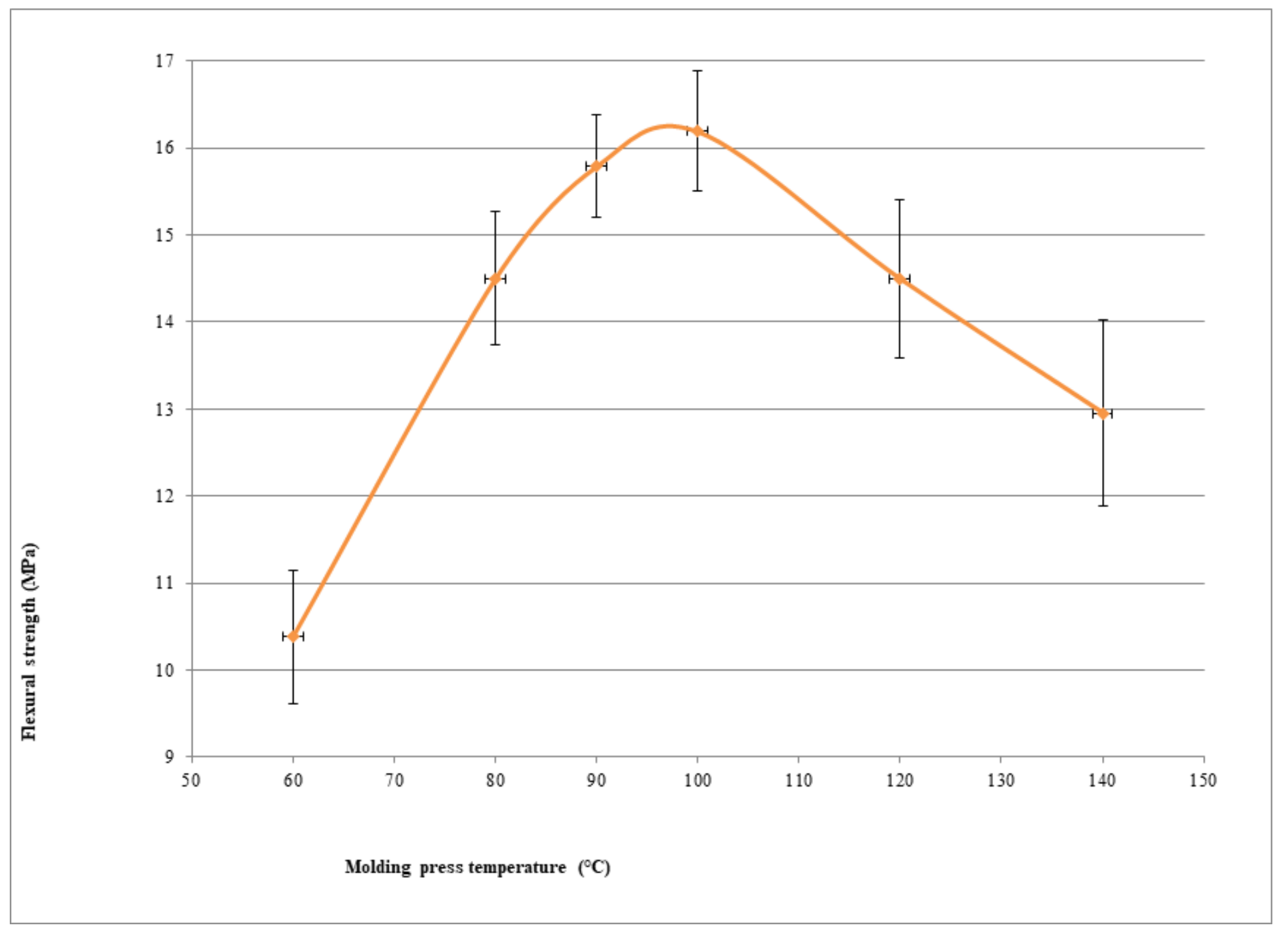

\section{Figure 4}

Determining of molding molding pressure-temperature ratio parameter in composite material production (Production conditions: $f / b: 0.25$, binder weight: 120 g, molding pressure: $28 \mathrm{~kg} / \mathrm{cm}^{2}$, max. grain size: 1 $\mathrm{mm}$, molding pressure time: 20 minutes) 


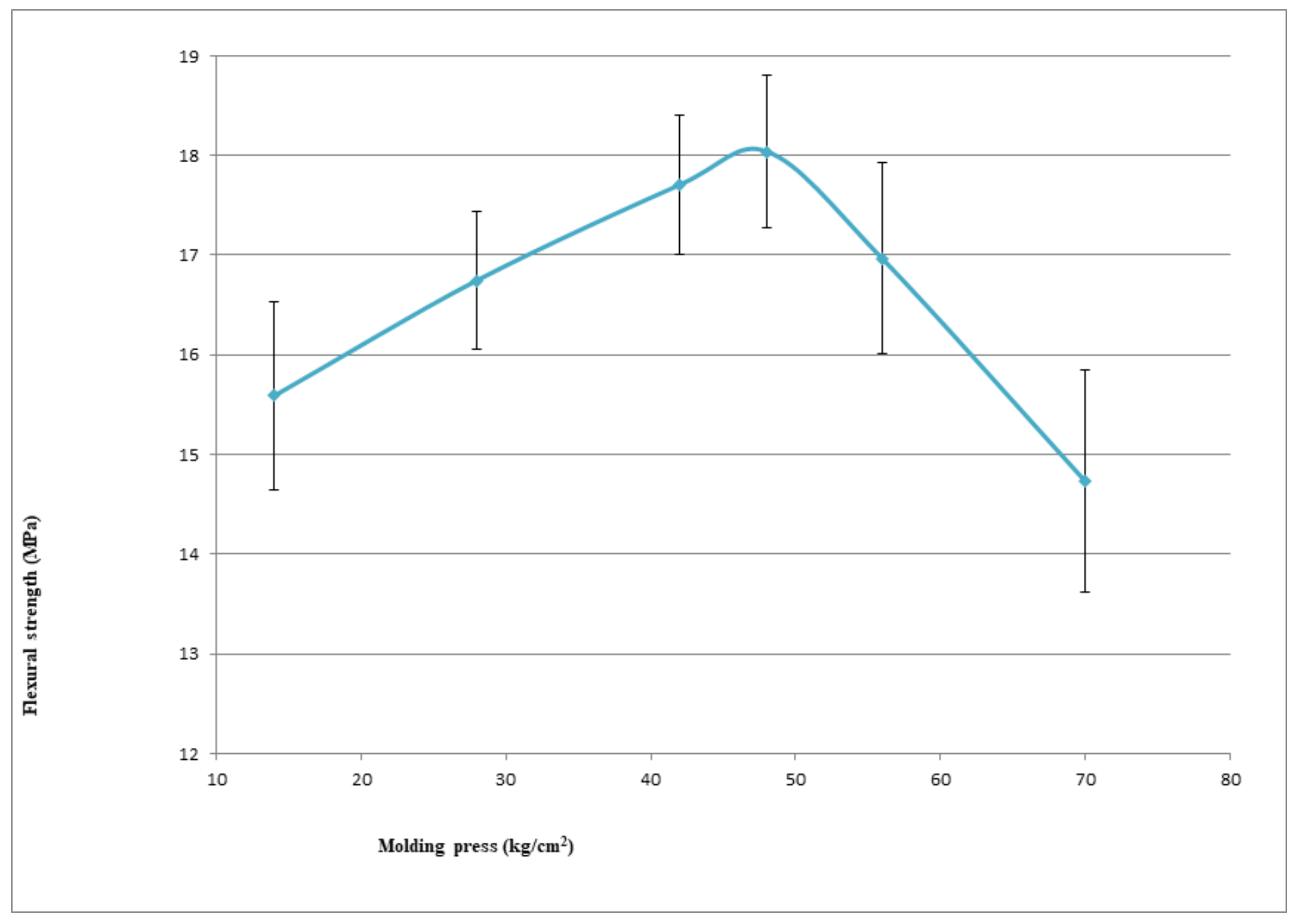

\section{Figure 5}

Determining of molding pressure parameter in composite material production (Production conditions: $\mathrm{f} / \mathrm{b}$ : 0.25 , binder weight: $120 \mathrm{~g}$, molding temperature pressure: $100^{\circ} \mathrm{C}$, max. grain size: $1 \mathrm{~mm}$, molding pressure time: 20 minutes) 


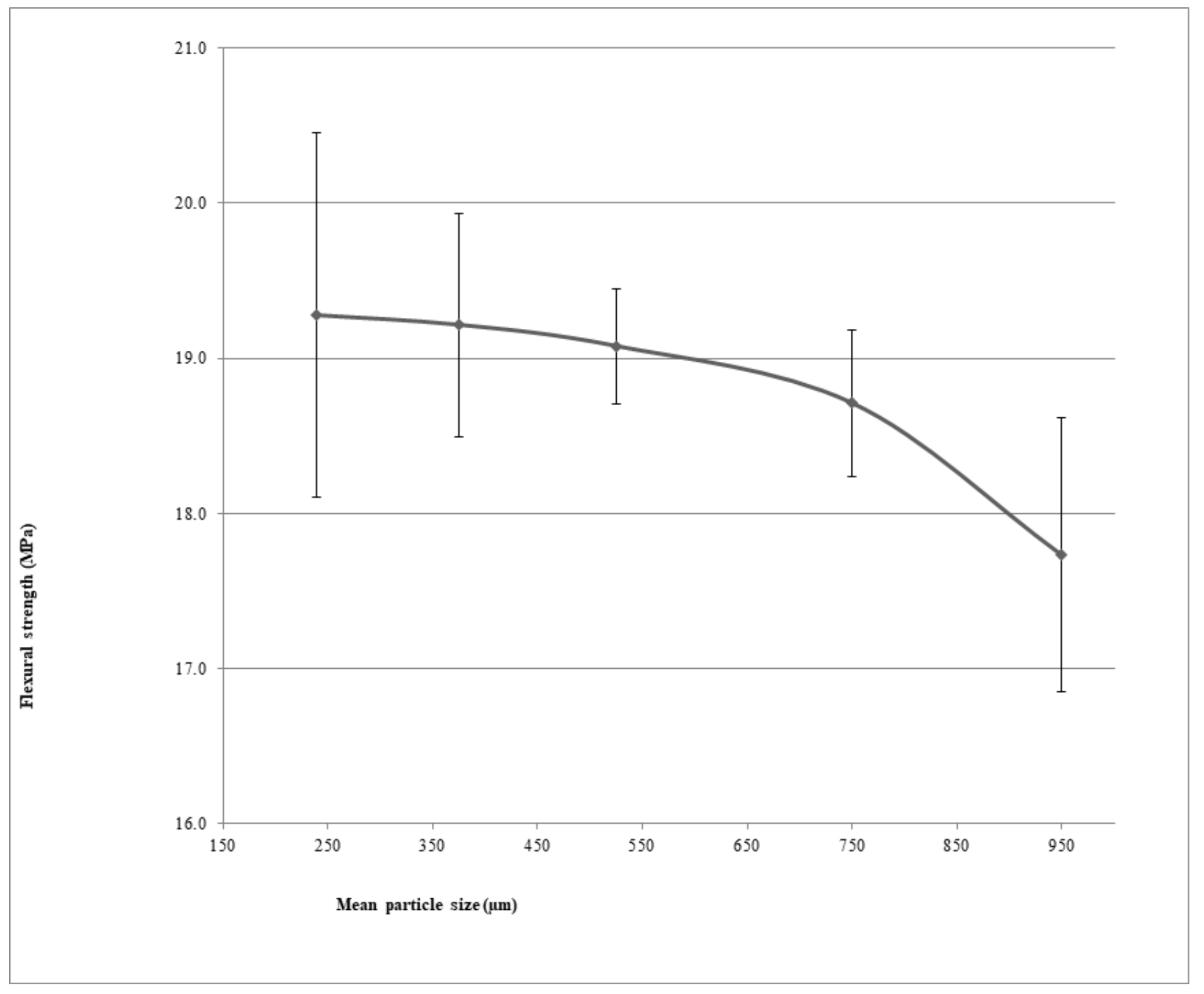

\section{Figure 6}

Determining of mean particle size parameters in composite material production (Production conditions: $\mathrm{f} / \mathrm{b}: 0.25$, binder weight: $120 \mathrm{~g}$, molding temperature pressure: $100{ }^{\circ} \mathrm{C}$, molding pressure: $49 \mathrm{~kg} / \mathrm{cm}^{2}$, molding pressure time: 20 minutes) 


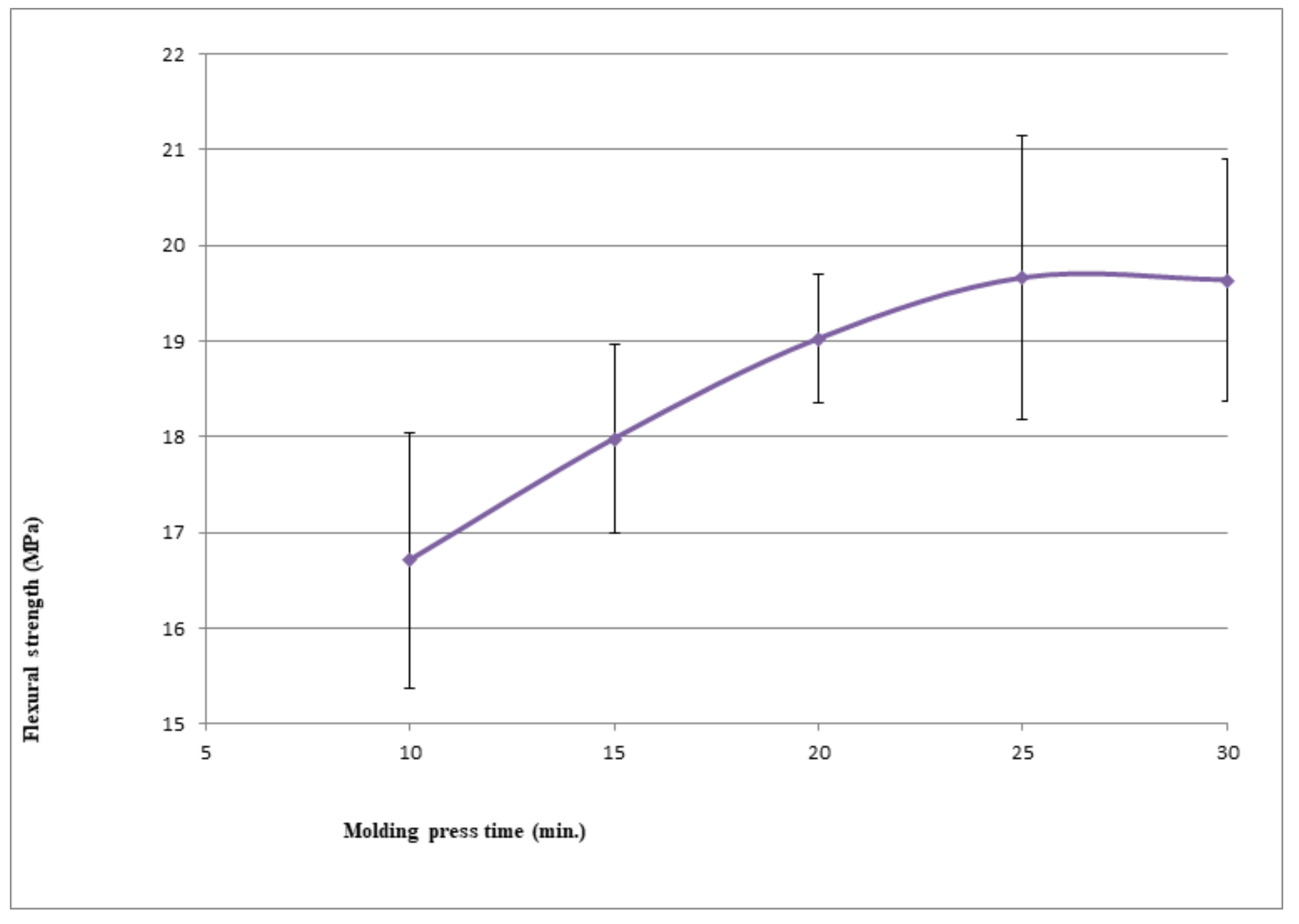

\section{Figure 7}

Determining of molding pressure time parameter in composite material production (Production conditions: $f / b: 0.25$, binder weight: $120 \mathrm{~g}$, molding temperature pressure: $100{ }^{\circ} \mathrm{C}$, molding pressure: 49 $\mathrm{kg} / \mathrm{cm}^{2}$, d: $240 \mu \mathrm{m}$ ) 


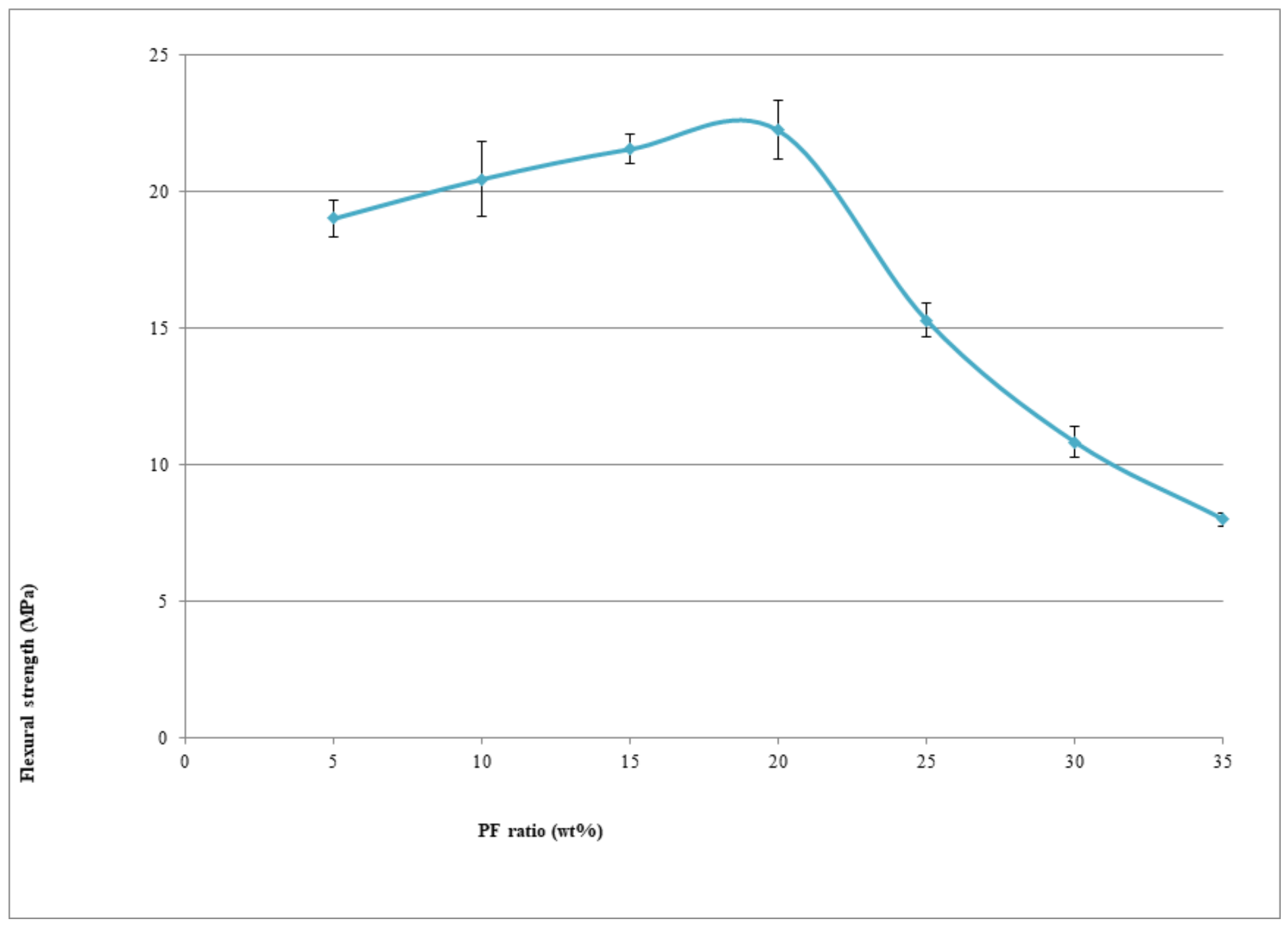

\section{Figure 8}

Determining PF ratio parameter in composite material production (Production conditions: $\mathrm{f} / \mathrm{b}: \mathrm{0.25}$, binder weight: $120 \mathrm{~g}$, molding temperature pressure: $100^{\circ} \mathrm{C}$, molding pressure: $49 \mathrm{~kg} / \mathrm{cm}^{2}, \mathrm{~d}: 240 \mu \mathrm{m}$, molding pressure time: 20 minutes) 


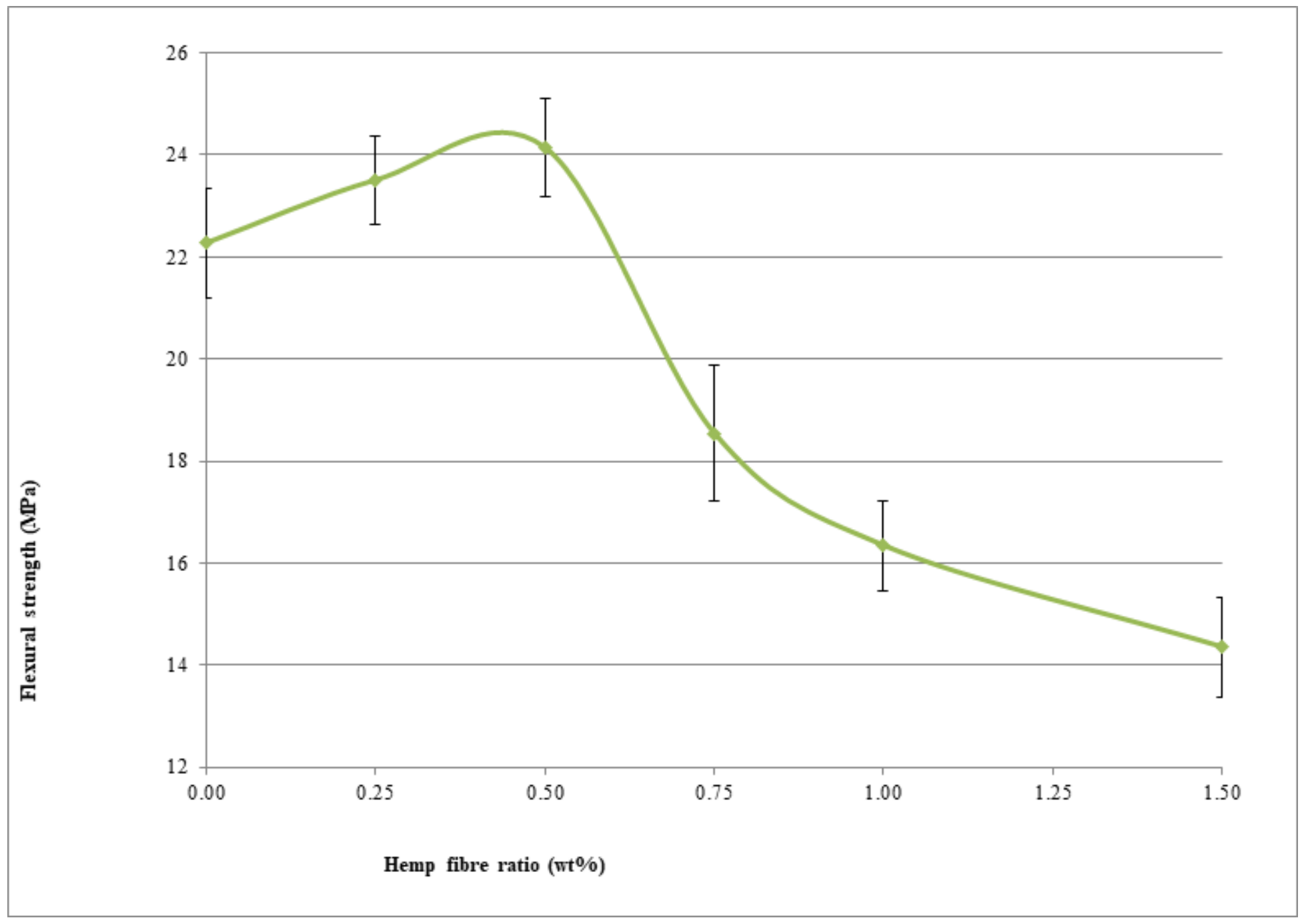

\section{Figure 9}

Determining hemp fiber ratio parameter in composite material production (Production conditions: $\mathrm{f} / \mathrm{b}$ : 0.25 , binder weight: $120 \mathrm{~g}$, molding temperature pressure: $100{ }^{\circ} \mathrm{C}$, molding pressure: $49 \mathrm{~kg} / \mathrm{cm}^{2}, \mathrm{~d}: 240 \mu \mathrm{m}$, molding pressure time: 20 minutes) 


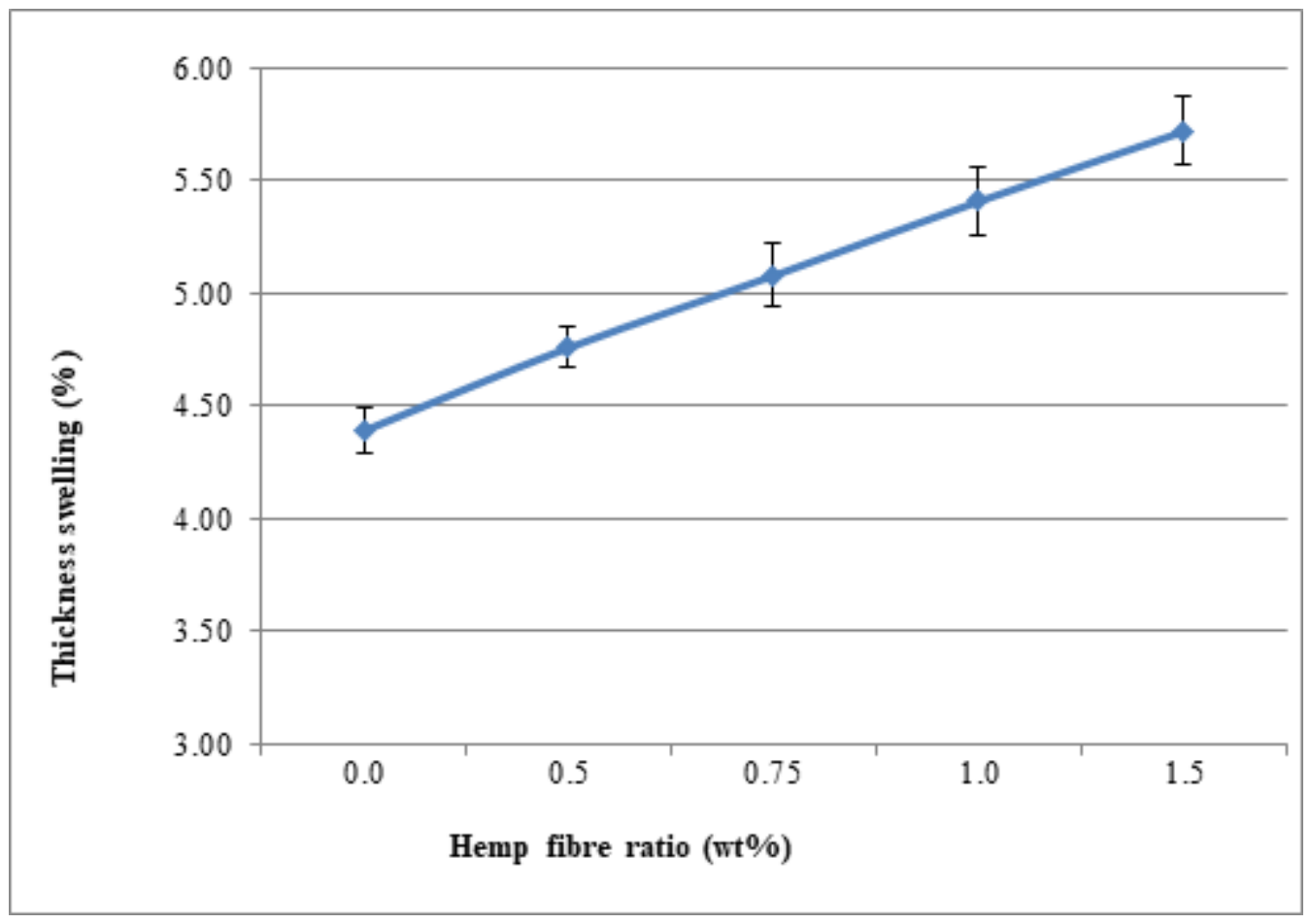

\section{Figure 10}

Thickness swelling values according to hemp fiber ratio (Production conditions: $f / b: 0.25$, binder weight:120g, molding temperature pressure: $100{ }^{\circ} \mathrm{C}$, molding pressure: $49 \mathrm{~kg} / \mathrm{cm}^{2}, \mathrm{~d}: 240 \mu \mathrm{m}$, molding pressure time: 20 minutes) 


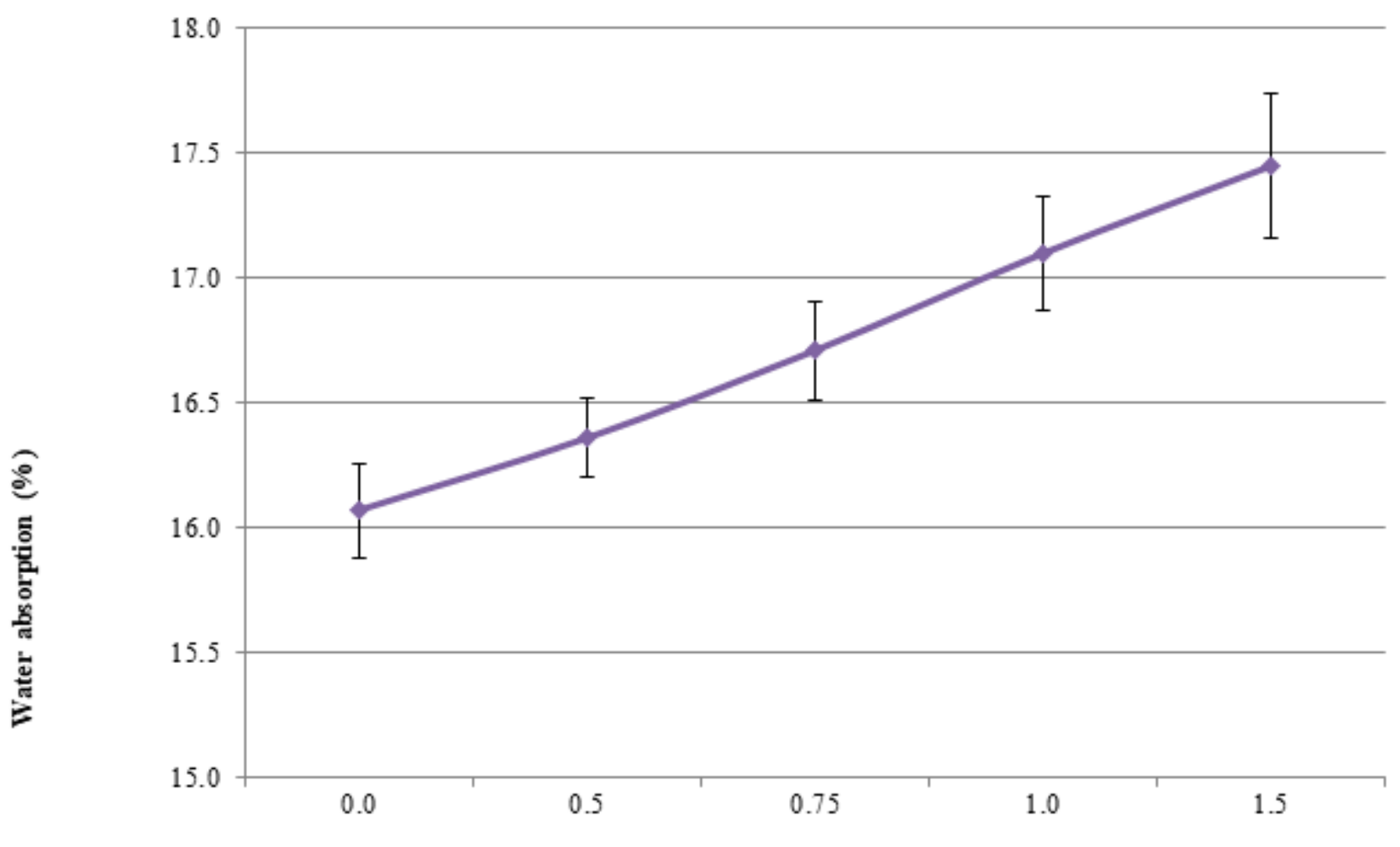

Hemp fibre ratio (wt \%)

\section{Figure 11}

Water absorption values according to hemp fiber ratio (Production conditions: $f / b: 0.25$, binder weight: $120 \mathrm{~g}$, molding temperature pressure: $100{ }^{\circ} \mathrm{C}$, molding pressure: $49 \mathrm{~kg} / \mathrm{cm}^{2}, \mathrm{~d}: 240 \mu \mathrm{m}$, molding pressure time: 20 minutes) 


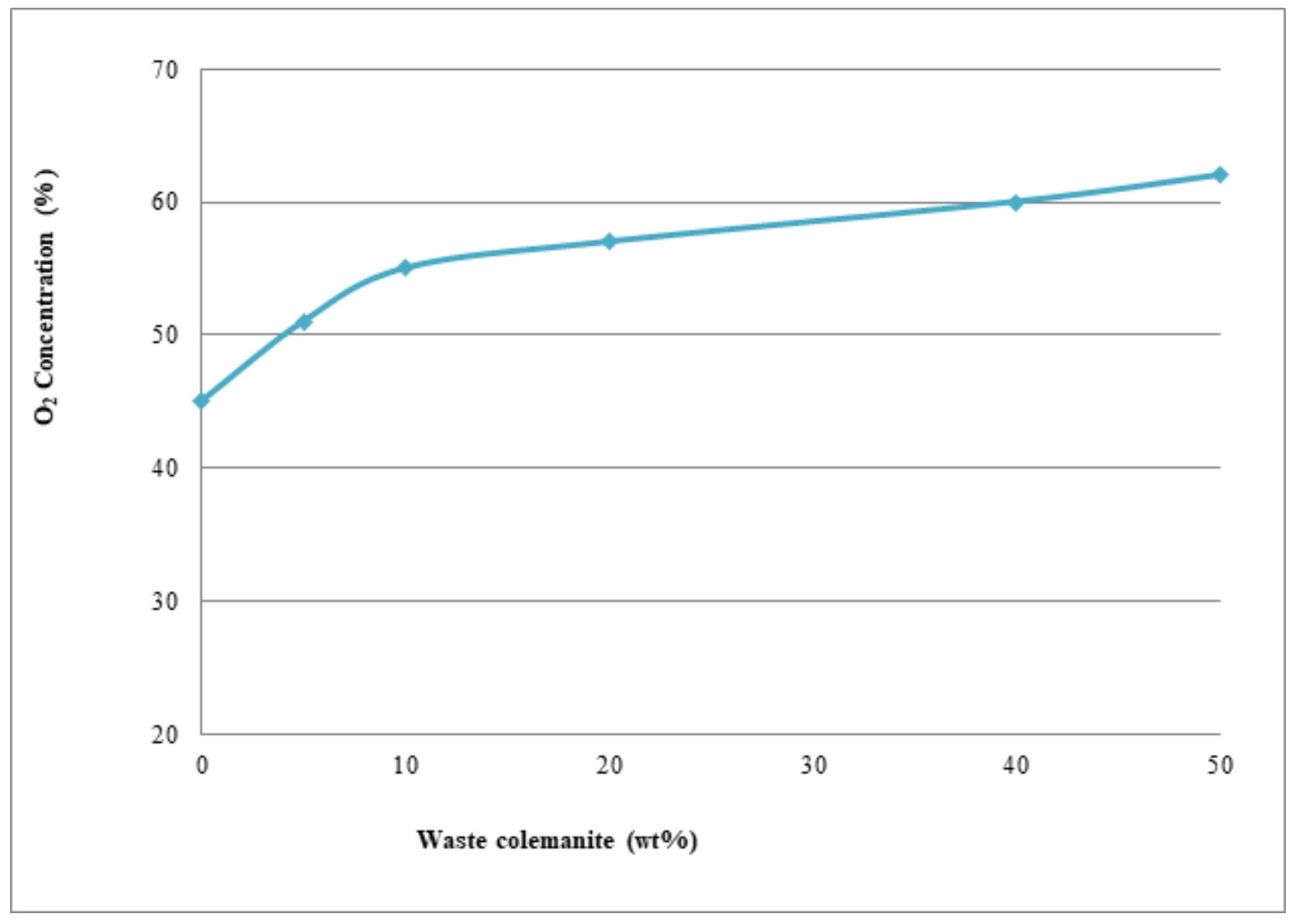

\section{Figure 12}

LOI level values of the waste colemanite based samples (Production conditions: $f / b: 0.25$, binder weight:120g, molding temperature pressure: $100{ }^{\circ} \mathrm{C}$, molding pressure: $49 \mathrm{~kg} / \mathrm{cm}^{2}, \mathrm{~d}: 240 \mu \mathrm{m}$, molding pressure time: 20 minutes, hemp fiber: \%0.5) 


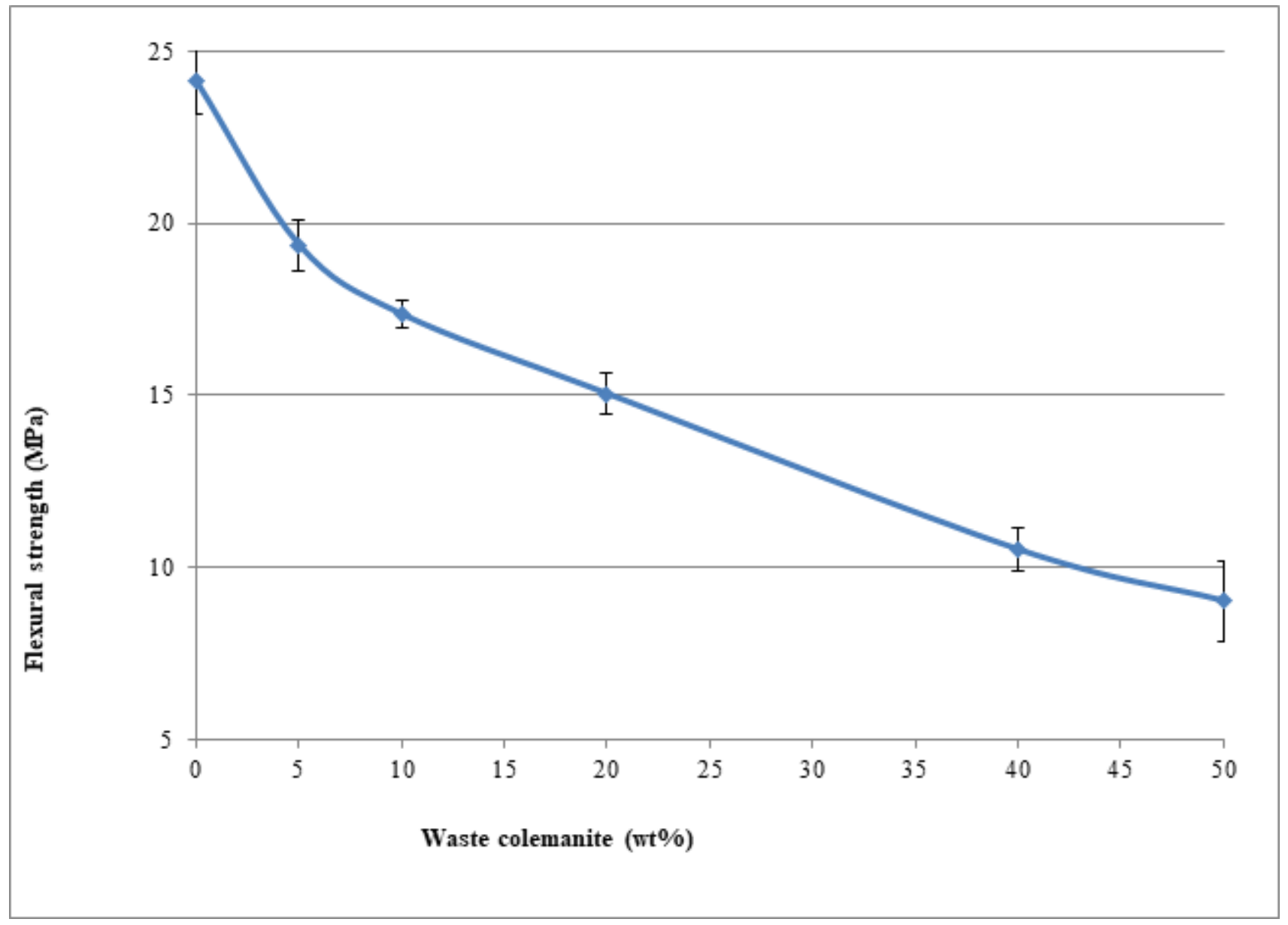

\section{Figure 13}

The flexural strength values of the samples in which waste colemanite is used (Production conditions:

$\mathrm{f} / \mathrm{b}: 0.25$, binder weight: $120 \mathrm{~g}$, molding temperature pressure: $100{ }^{\circ} \mathrm{C}$, molding pressure: $49 \mathrm{~kg} / \mathrm{cm}^{2}, \mathrm{~d}: 240$ $\mu m$, molding pressure time: 20 minutes, hemp fiber: \%0.5) 


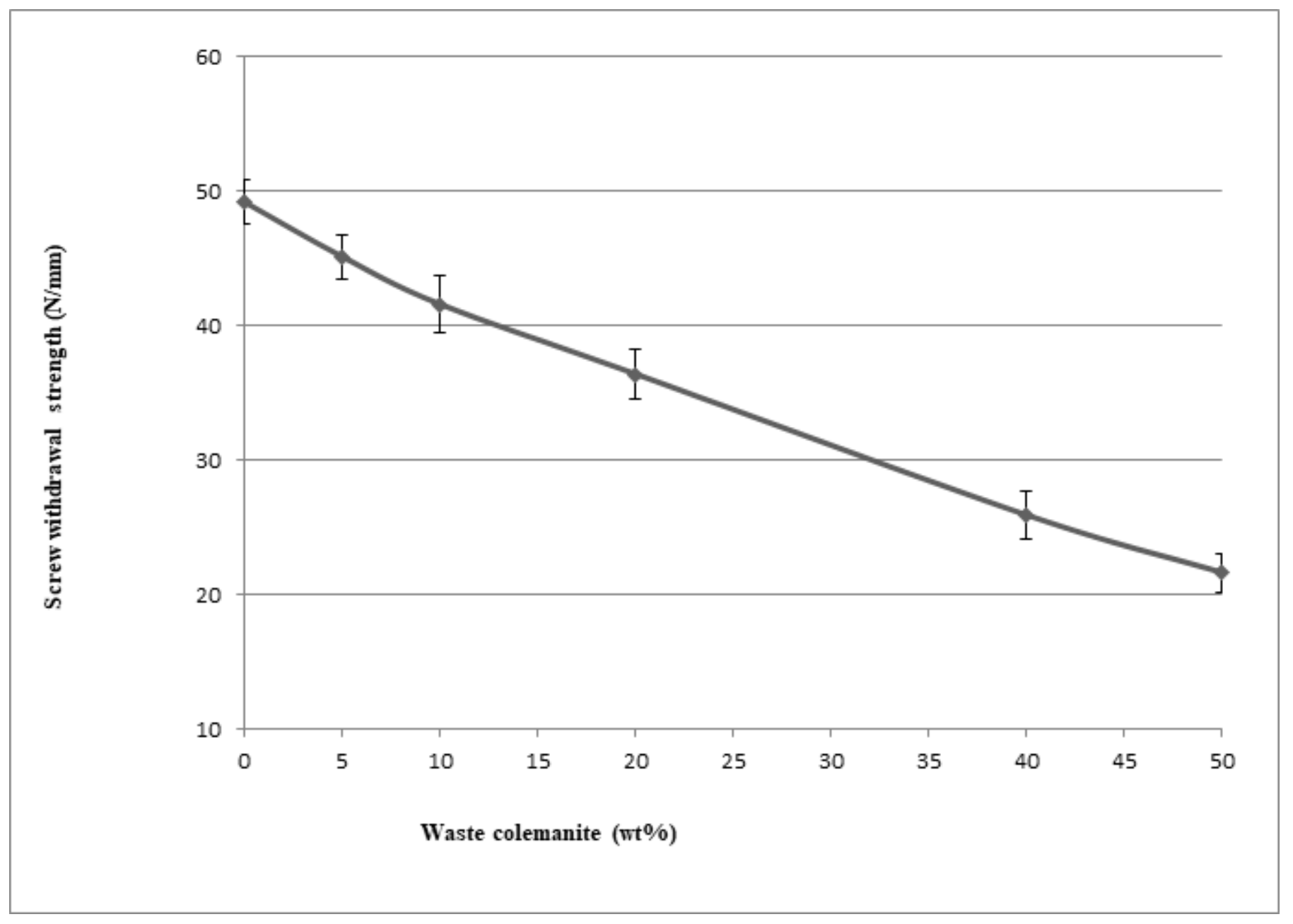

\section{Figure 14}

The screw withdrawal strength values of the samples in which waste colemanite is used (Production conditions: $\mathrm{f} / \mathrm{b}: 0.25$, binder weight: $120 \mathrm{~g}$, molding temperature pressure: $100^{\circ} \mathrm{C}$, molding pressure: 49 $\mathrm{kg} / \mathrm{cm}^{2}, \mathrm{~d}: 240 \mu \mathrm{m}$, molding pressure time: 20 minutes, hemp fiber: \%0.5) 